Using attachment theory to illuminate consumers' tensions between their sense of self and goal-pursuits in relationships

\begin{abstract}
Consumers face tensions in deciding which goal to pursue, who to be and which self to present in daily life. Yet we know little about these tensions consumers experience as they respond to distinct interpersonal contexts (e.g., perceived support, trust, conflict and sense of belongingness). To this end, we explore the consumption deliberations that consumers undertake for self-presenting when faced with varying interpersonal encounters. We used interview data with women aged 19-62 and Rabinovich and Kacen's (2013) qualitative coding methodology to examine interpersonal patterns of self-presentation. During the data analysis, attachment theory emerged as important in illuminating the tensions participants experienced in pursuing 4 types of goal-pursuit (intimacy, prevention, performance and authenticity) aided by their consumption choices for self-presenting in specific interpersonal contexts. Our findings show intrapsychic and interpersonal influences are not non-interacting entities, but rather need to be studied in conjunction when examining how people create desired social images/identities.
\end{abstract}

Keywords: Goal-pursuit, Interpersonal relationship, Interpersonal context, Personal adornment, Tension, Attachment theory 


\section{Using attachment theory to illuminate consumers' tensions between their sense of self and goal-pursuits in relationships}

\section{Introduction}

In postmodernity, we are encouraged to draw on a diverse range of consumption choices to be whoever we want to be (Firat \& Venkatesh, 1995). However, studies have highlighted that consumers often experience tensions when exercising these consumption choices (Ahuvia, 2005; Ruvio \& Belk, 2018; Tian \& Belk, 2005). Arguably, this is especially the case with consumption closely related to personal adornment, the practice of cultivating one's body and appearance such as clothing, make-up, tattooing, plastic surgery and the like (Larsen, Patterson, \& Markham, 2014; Ruvio \& Belk, 2018; Schouten, 1991). Murray (2002) argued that consumption choices for self-presentation can be a source of tension where "issues related to competing subjective positions, difference, and identity politics are marked and experienced" (p., 433). In order to resolve such tensions, consumers declare both who they are - and who they are not - by combining, adapting and personalizing fashion discourses (Thompson \& Haykto, 1997). However, by turning to consumption as a solution to resolve such tensions, the solution can create new forms of tension (Ruvio \& Belk, 2018).

Past consumer research has shown that a sense of tension is often felt when consumers engage in consumption deliberations to decide between who I want to be, focusing on the exercise of consumer agency, and who I should be, emphasizing the importance of adhering to appropriate socio-cultural conduct. Here, consumption engaged in to present who I want to $b e$ is often conceptualized as a means of communicating our expression of the perceived authentic self. On the other hand, consumption used to advocate who I should be is usually thought of as involving efforts to conceal one's natural way of being that might undermine social acceptance.

Yet, while insightful, prior consumer research, when examining the role of consumption choices in creating identity tensions, has tended to focus mainly on the tensions 
between individual consumers and the wider cultural ideologies. Little is known about the tensions consumers may also experience as they deliberate consumption choices in deciding which goal to pursue, who to be and which self to present in distinct interpersonal contexts (e.g., perceived support, trust, conflict and sense of belongingness). To explore this topic, our research objective is to examine the consumption deliberations that consumers undertake for self-presenting when faced with varying interpersonal encounters. Specifically, we ask (1) what are the goals consumers pursue in relation to their self-presentations? And, (2) what are the tensions consumers might experience in pursuing these goals as they respond to distinct interpersonal contexts? We answer these questions by investigating the various ways our women participants describe their personal adornment efforts to achieve specific goals in interpersonal exchanges. Whereas self-presentation is arguably the most important and prevalent task of the self across interpersonal contexts, the tensions involved in coming to terms with which goal to pursue and which self to be may be its most important intrapsychic task (also see Vohs, Baumeister, \& Ciarocco, 2005 on self-regulation).

This study draws on attachment theory (AT) to help shed light on the study phenomenon. During the course of our data analysis, Bartholomew and Horowitz's (1991) model of adult attachment styles emerged as highly relevant to the ways in which our participants made sense of the consumption choices that aided their self-presentation in distinct interpersonal contexts. Attachment styles have been used to explain consumer behavior in the context of relationships (Mende, Bolton, \& Bitner, 2013; Nguyen \& Munch, 2011, 2014; Thomson, Whelan, \& Johnson, 2012) and the goals individuals pursue in interpersonal exchanges (Mikulincer \& Shaver, 2016). More recent research has identified both stability and change in individuals' attachment styles as they respond to ongoing interpersonal experiences (Fraley, Vicary, Brumbaugh, \& Roisman, 2011; Gillath, Karantzas, \& Fraley, 2016; Stern et al., 2018). In the light of our findings, we view attachment styles as 
dimensional (Fraley, Hudson, Heffernan, \& Segal, 2015), which can help illuminate the tensions our participants experienced between their sense of self and the goals they sought to achieve through their self-presentation in distinct interpersonal contexts.

\section{Consumers and their self-presentation}

Research has long indicated heterogeneity in self-presentation across relationships (Snyder, 1987). Leary and Allen (2011) argue that firstly, people tailor their public images to specific audiences, and secondly, a broader variety of self-presentation behaviors are engaged with when interacting with close others rather than with non-close others. In addition, Øverup and Neighbors (2016) suggested that individuals engage in differing levels of self-presentation, depending on the perceived closeness to and trust in the socializing other(s). That is, when people feel close to and have trust in a person, they tend not to feel as urgent a need to portray a favorable self-image, although this feature was recorded somewhat inconsistently in that study. In sum, we know that different self-presentations often reflect a variety of goalpursuits in relationships. Yet, little is known about how these goals operate in specific interpersonal contexts (Øverup \& Neighbors, 2016).

In the consumption setting, earlier studies have established the importance of cultivating specific self-presentations through pesonal adornment as a means of achieving a variety of identity and/or relationship goals (Askegaard, Gertsen, \& Langer, 2002; Russell W. Belk, 2003; Liu et al., 2016; McAlexander \& Schouten, 1989; Ruvio \& Belk, 2018; Schouten, 1991). McAlexander and Schouten (1989) show how hairstyling could help consumers facilitate identity transition. Huang and $\mathrm{Yu}$ (2000) find products used to enhance selfattractiveness play a role in maintaining romantic relationships. Liu, Keeling, and Hogg (2016) identify how women used make-up to cope with a series of wellbeing challenges (including the need to fit in, or to create intimacy). Seregina and Weijo (2017) argue that costuming or cosplay is a means of aiding identity play and creating community feeling. In 
the meantime, many researchers have shown that consumers often experience tensions in their choices of personal adornment, negotiating between "who I want to be" and "who I should be" (Murray, 2002; Ruvio \& Belk, 2018; Thompson \& Haytko, 1997). Ruvio and Belk's (2018) work, for example, underlies the tensions transpeope often experience in choosing how to adorn the self, reflecting their struggle in trying to harmonize social norms and perceivd authentic self-presentation. These studies tend to focus firstly, on consumers' appropriation of countervailing cultural meanings, and secondly, at the level of their selfpresentation. We therefore still know little about the role of interpersonal contexts in influencing the tensions consumers experience as they deliberate about which goal to pursue, who to be and which self to present.

\section{Attachment theory and styles}

Bartholomew and Horowitz's (1991) model of adult attachment styles emerged as important in illuminating the reasons behind our participants' various uses of personal adornment in specific interpersonal contexts. There has been an increasing application of AT from psychology to the consumer behavior context (e.g., Nguyen \& Munch, 2011; Paulssen, 2009; Thomson et al., 2012; Whelan, Johnson, Marshall, \& Thomson, 2016). One reason for this is that attachment theory is one of the most comprehensive and leading theoretical frameworks for explaining how people approach and behave in interpersonal relationships (La Guardia, Ryan, Couchman, \& Deci, 2000; Mikulincer \& Shaver, 2016; Nguyen \& Munch, 2014). Attachment research argues that there are two types of internal working models: an internal model of the self and an internal model of others. Each internal model can be dichotomized as positive or negative. The interaction of the two internal models, according to Bartholomew and Horowitz (1991), produces four distinct attachment styles that function as social schemas to influence an individual's goal-pursuits. The four attachment styles are labelled as secure, preoccupied, fearful-avoidant and dismissing-avoidant (see figure 1). 


\section{INSERT FIGURE 1 HERE}

The internal model of the self is concerned with "how acceptable the self is in the eyes of early attachment figures, as gauged from the responsiveness of those figures" (Pietromonaco \& Barrett, 2000, p.156). That is, children whose attachment figures are readily available, receptive and dependable are believed to develop positive self-images that view the self as worthy of connection and inherently acceptable in social interplays. They are thus less dependent on others for fostering a sense of the positive self. In contrast, those who have ambivalent, rejecting or uncaring attachment figures are thought to develop negative selfimages that view the self as not worthy and unacceptable. As a result, they tend to rely on others' approval to maintain a positive self-regard. The internal model of others, on the other hand, is assumed to reflect one's beliefs about whether anyone, and the attachment figures in particular, will respond when needed in a helpful way (Main, Kaplan, \& Cassidy, 1985; Pietromonaco \& Barrett, 2000). These beliefs then influence the degree to which one approaches or avoids close contact with others.

People who hold positive images of both the self and others are characterized by a secure attachment. They generally display high self-esteem, focus on authentic selfexpression, and pursue both intimacy and self-autonomy in relationships. They view interpersonal closeness as not only "a safe haven" where they can " retreat for comfort, support, reassurance, assistance, and protection" but also "a secure base" from which to explore the world and strive to meet their full potential (Feeney, Van Vleet, Jakubiak, Simpson, \& Rholes, 2015, p., 196). Here, closeness and autonomy are complementary and not antagonistic goals.

In contrast, both preoccupied and fearful consumers are driven by the need for others' acceptance in order to gain a sense of self-worth. However, they differ in their inclination to approach others. A preoccupied (also called anxious) attachment style would orient 
consumers to overemphasize closeness-related goals, and focus on seeking excessive reassurance from others that the self is desirable and loved (Banai, Mikulincer, \& Shaver, 2005; Brennan \& Bosson, 1998; Ren, Arriaga, \& Mahan, 2017). For example, Nguyen and Munch (2011) found that gift givers' attachment anxiety leads them to experience gift giving as obligated. This is perhaps because of the inherent quality of gift giving in allowing the gift giver to create and strengthen relationship bonds (Ruth, Otnes, \& Brunel, 1999; Sherry, 1983) - a quality that could help boost closeness-related goals. A fearful-avoidant attachment style, on the other hand, characterizes people who seek social approval but avoid bonding with others as a means of self-protection against anticipated rejection by others. In the consumption setting, there is evidence that consumers who emphasize the need for others' acceptance, but fail to form strong and meaningful attachments to friends and family, may be more prone to seek attachments to material goods (e.g., clothes, brands etc.) as a substitute for their faltering interpersonal relationships (Arndt, Solomon, Kasser, \& Sheldon, 2004; Rindfleisch, Burroughs, \& Wong, 2009). This is because material goods may serve as relationship partners (Fournier \& Alvarez, 2012; Thomson et al., 2012) (hence diminishing the need for person relationships) and/or as a means for signaling consumers' ideal self to potential social others (Liu, Keeling, \& Hogg, 2012; Swaminathan, Stilley, \& Ahluwalia, 2009) (therefore improving their chances of being accepted).

Finally, like those in the fearful cell, persons who have a dismissing-avoidant attachment style also see close relationships as threatening because of the potential for eventual disappointment. Yet, unlike preoccupied and fearful consumers who harbor negative self-images, the dismissing-avoidant does not depend on others for a positive self-regard. They maintain independence, autonomy and invulnerability by seeking distance-related, nonrelational goals and denying their need for belongingness (Ren et al., 2017). 
In sum, a central tenet of AT is the innate human need to establish a psychological sense of felt security in relationships (Pietromonaco \& Barrett, 2000; Ren et al., 2017). Depending on the attachment style of the individual, s/he may seek different goals to achieve felt security in relationships. Recent consumer research has successfully applied AT to better understand how consumers' attachment styles may influence their marketplace relationships (e.g., brands, B2B, advertising effectiveness) (David, 2016; Paulssen, 2009; Thomson et al., 2012; Whelan et al., 2016). These studies typically treat attachment styles as trait-like, reflecting global models of the self and others in close relationships. Yet, Bowlby (1973), a pioneer in the field of AT, has long argued that the organization of the attachment system, while being relatively stable, can be updated in response to environmental changes. Recent advancements in AT research have also evidenced that people's attachment styles can have contextual variability as they go through major life events that contribute to shifts toward insecurity or security, such as interpersonal losses (Kirkpatrick \& Hazan, 1994; Sbarra \& Hazan, 2008), transitions to parenthood (Stern et al., 2018) and the processes of aging (Chopik, Edelstein, \& Fraley, 2013). Attachment styles may also be relationship specific and thus may or may not be reflective of an individual's global attachment styles (Collins \& Read, 1994; Fraley et al., 2011). In the context of gift exchange, for instance, Nguyen and Munch (2014) found evidence that both individuals' global and relationship-specific attachment styles can play a role in shaping their gift giving perceptions. Therefore, attachment styles can be considered as both global and relationship-specific and as having both trait-like and state-like qualities (Fraley \& Roberts, 2005). In presenting our findings, we show how the interplay between relationship-specific, contextual factors (people's relational selves and schema models) and stable, global attachment styles (secure, preoccupied, fearful-avoidant and dismissing-avoidant) may help illuminate our understanding of consumers' consumption deliberations about self-presenting in distinct interpersonal contexts. 
This paper continues by describing the methods and then presenting our findings. At the beginning of our findings section, we offer an organizing overview before exploring detailed cases that draw out the key themes and interweaving our interpretations with relevant literature. We conclude with a theoretical discussion and suggest avenues for future research.

\section{Methods}

\subsection{Data collection}

We chose personal adornment as our research context to explore the consumption deliberations that women consumers engage in to determine which goal to pursue, who to be and which self to present in distinct interpersonal contexts. Previous research has indicated that the everyday mundane choices about levels and types of personal adornment provide an important clue for understanding consumers' goal-pursuits and the potential tensions they might experience in pursuing these goals (Larsen et al., 2014; Murray, 2002; Ruvio \& Belk, 2018). Women in particular are often characterized as relational beings (Thompson, 1996) who vary their uses of personal adornment to feel empowered, conceal vulnerabilities and form close connections with others (Liu et al., 2016; Scott, 2006). How and why women use personal adornment to cultivate self-presentations thus presents a rich context in which to examine our proposed research objective and research questions.

To this end, we sought to recruit women who tended to wear make-up in their everyday lives through personal contacts and referrals - this is because make-up is central to women's consumer culture. The make-up product category "represents an essential, yet mundane, means of self-reinvention and transformation, and allows women to articulate different aspects of the self at ease, including both positive and negative" (Liu et al., 2016, p.236). It also gave our participants a clear springboard from which to talk about other forms of personal adornment in complementing or completing a specific look they seek to achieve. 
Data collection continued until no new theoretical insights could be obtained. As a result, thirty-one women, living in the United Kingdom and ranging in age from 19 to 62 , were interviewed (see table 1). The first author conducted all the interviews either in person or via video calls. Each interview started with questions around personal backgrounds and our participants' thoughts about their make-up use in helping them achieve different looks and self-presentations. The interviewer then followed the course primarily set by each informant while prompting these women to continue to reflect on their personal adornment efforts and how these efforts are experienced in a variety of interpersonal encounters. In addition to make-up, skincare/tanning products, clothes, shoes, hairstyling and plastic surgery were also mentioned in our participants' interview dialogues. Each interview was transcribed verbatim and lasted between 1-2 hours.

\section{INSERT TABLE 1 HERE}

Six months after the initial interview, a further round of emails was sent to request a second interview with participants who felt that they had experienced changes in how they adorned the self. Eleven participants (out of the original 31) responded to the email and took part in follow-up interviews. They reflected on changes in their use of personal adornment, particularly their make-up routines. These follow-up interviews lasted around 30 minutes on average. In analyzing these two rounds of interviewing, we focused on systematically examining if these women's interview descriptions of personal adornment exhibit certain regularities - from which it was then possible to elicit a structure, expressed in a set of interpersonal patterns.

\subsection{Data analysis}

Table 2 shows how we used Chloe's account as an exemplar to demonstrate the ways in which we have systematically coded each participant's account. We followed Klein, Lowrey, and Otnes (2015) in our coding approach. We engaged in an iterative process in which 
literature on self-presentation and goal-pursuits was brought to bear in developing a "thick description" (e.g., lived experiences of how personal adornment is experienced), as withinand cross-case analysis evolved in a series of drafts. Specifically, we adapted Rabinovich and Kacen's (2013) qualitative coding methodology to interpret participants' experiences of their personal adornment uses and what they said they sought to achieve when interacting with others. Rabinovich and Kacen (2013) advocate the use of Luborsky and Crits-Christoph's (1998) interpersonal sphere and core conflictual relationship themes coding methods combined with the coding technique of overgeneralization (Epstein, 1992). These coding practices allowed us to systematically examine interpersonal patterns, while also identifying bilateral, trilateral, and quadrilateral relationships that emerge from these patterns (as defined in table 2).

\section{INSERT TABLE 2 HERE}

What became clear in this process were the strong resemblances between AT and the distinct interpersonal contexts we identified in our informants' accounts that appeared central in influencing their internal debates about which goal to pursue and the different ways of presenting/adorning the self. As we will demonstrate in our findings, we consistently discovered an underlying interaction of internal working models of the self and others - akin to that theorized by Bartholomew and Horowitz's (1991) adult attachment model underpinning our informants' consumption deliberations for self-presenting in distinct interpersonal contexts. As such, we use the existing labels of attachment styles to define the four interpersonal contexts we found our informants describing in our study, namely, secure, preoccupied, fearful-avoidant and dismissing-avoidant. Table 3 shows the specific interpersonal contexts that underpin the four types of goal that our informants pursued through their self-presentations. We also show the salient dimensions of each goal that our informants pursue and the tensions they experience in specific goal-pursuits. 


\section{INSERT TABLE 3 HERE}

\section{Findings}

Our participants describe their personal adornment use as largely influenced by the interpersonal context they anticipate themselves to be in and the goals they seek to achieve in that context. In figure 2, we show a preliminary framework that draws our findings into a coherent whole (cf., Fraley et al., 2015). More specifically, we show in our data that depending on whether our participants' uses of personal adornment are intended to enhance or conceal the self in interpersonal contexts, the resultant self-presentation may be experienced as representing either "me" or "not me".

\section{INSERT FIGURE 2 HERE}

Below, we organize our findings by the four interpersonal contexts highlighted in figure 2. It is important to note, however, that a large proportion of our participants' descriptions relating to their goal-pursuits and self-presentation choices seem to be driven by an interaction between their perceived low self-worth (negative self-image) and low trust in others for self-acceptance (negative other-image) (akin to a trait-like fearful-avoidant attachment style). This is perhaps not surprising as our participants are consumers who regularly wear make-up and engage in personal adornment to enhance or transform their perceived self (also see Fredrickson \& Roberts, 1997; Strelan \& Hargreaves, 2005). For illustration, we present Kylie, Chloe, Emma and Jill's accounts about how they vary their uses of personal adornment to achieve goal-pursuits in distinct interpersonal contexts, and the tensions that might arise in pursuing these goals. The four case studies were chosen because they were representative of the interviews as a whole, and offered rich illustrations of the major findings (e.g., the relationship-specific, contextual factors that influence consumption deliberations) (see table 4). Table 4 offers an overview of Kylie, Chloe, Emma and Jill's 
personal backgrounds and the attachment styles they seem to be exhibiting in their descriptions of their interpersonal interactions across contexts.

\section{INSERT TABLE 4 HERE}

The overview presented in Table 4 helped us capture both the informants' early experiences with significant others and their immediate interpersonal circumstances (as illustrated in detail in our findings below) that together play an influential role in influencing their goals and experiences of being (Mikulincer \& Shaver, 2016; Pietromonaco \& Barrett, 2000).

\subsection{In a secure interpersonal context}

\subsubsection{The intimacy goal}

The intimacy goal (Figure 2, upper right) emerges to guide self-presentation when the participant increasingly (1) acknowledges and tolerates her limitations, yet still feels confident and positive about the self (i.e., positive self-image); and (2) trusts that her significant others, social groups and/or the outside world as a whole, will not abandon her if they learn about her perceived flaws (i.e., positive other-image). The combination of positive self- and positive other-images appears to facilitate a perceived safe environment (i.e., $a$ secure interpersonal context) where the revelation of perceived self-flaws helps develop greater intimacy, connection and trust in interpersonal exchanges (Laurenceau, Barrett, \& Pietromonaco, 1998). Emma's description of disabled people captures how the presentation of the unadorned self, especially in public spaces, can be seen as a potential source of stigmatization (Goffman, 1963): "When I am walking in the street people don't notice that [my bare skin] and they don’t think “oh, God”. I always feel very sorry if people have disabilities because people would turn and look at them". The extent to which participants feel close to their socializing other(s), however, seems to moderate this fear of stigmatization. 
Emma continued to reflect on the changes in her use of personal adornment in a romantic relationship over time:

When I first met him [my partner], I made lots of efforts. You want him to think you are really pretty, I definitely put concealer on as soon as I woke up...Then when I moved in with him it's a bit different because then he always sees me in the shower and I can't help, I can't wear make-up in the shower and then I just thought this is ridiculous, he obviously loves me for the way I am, and I just really slowly wearing less. It's been like two years [since we started dating], if I have a big spot I would put a big lump of cream on it... whereas I would never have done that [before], I think he loves me for who I am.

We see here Emma's growing willingness to present her unadorned self when the perceived relationship bond deepens. The importance of self-disclosure and partner responsiveness in creating meaningful connections and intimacy has long been recognized in psychology (Laurenceau et al., 1998; Mashek \& Aron, 2004; Øverup \& Neighbors, 2016). Salient to our context, we relate the term self-disclosure to the willingness to disclose the (relatively) unadorned (or untransformed) self and focus more on authentic self-expression. Failing to self-disclose in close relationships can undermine perceived intimacy (Laurenceau et al., 1998). Olivia expresses her frustration about never seeing her girlfriends' make-up free selves:

I know a few girls - they just absolutely no chance to let somebody see them without make-up on. I've known them for years...if they were comfortable to do that [not wear make-up in front of me all the time], that would be nice, because it's like without a mask and it's like they kind of trust you... it's like you getting to know a different side of them.

Olivia's girlfriends' reliance on personal adornment for self-presentation may be driven 
by the goal of prevention or performance, instead of intimacy, as we will discuss in the subsequent relevant themes.

\subsubsection{Tensions in pursuit of intimacy}

Our informants largely experience the presentation of their unadorned self here as the path to achieving intimacy and the authentic self (this is me). However, there is a tension. Jill talks about this sense of tension:

J: I suppose you start to dress up a bit more when you get somebody...You still want to keep that romance going for as long as you can. Of course after a while, you don't care about that much and you just think that would do...I feel more relaxed.

I: How do you feel about passing this phase?

J: I wish I hadn't, I really do. I used to love the buzz of looking for new make-up, new clothes, going out and meeting my partner.

As seen in this quote, while admitting a sense of relief about not having to worry about adorning the self for love, this sense of relief is clearly layered with Jill's mourning about losing "the buzz" in the relationship. This is because the unadorned self is perceived to limit one's ability to present an enhanced self-image that helps achieve relevant interpersonal rewards (Lemay Jr, Clark, \& Greenberg, 2010).

Observing the language Emma used, in the preceding section, to describe her growing willingness to self-disclose and present her unadorned self to her partner, Emma also seems to have experienced some form of reluctance in forgoing personal adornment as her relationship matures (e.g. "I can't help it", "I can't wear make-up in the shower" and "this is ridiculous"). Part of Emma's reevaluation of make-up use seems to spring from the ridiculousness she felt at her own persistent craving for perfection and the impossibility of achieving this (also see table 4).

\subsection{In a preoccupied interpersonal context}




\subsubsection{The prevention goal}

Our data points to the central role of the prevention goal (Figure 2, bottom right) in guiding self-presentation when one (1) experiences the self as of little worth, wishes to be different from what she is, and often internalizes blame for problems (negative self-image); but (2) appreciates her socializing others' love and acceptance are unconditional (positive otherimage). Resulting from the combination of negative self- and positive other-images (i.e., $a$ preoccupied interpersonal context) is a focus on self-protection achieved through socially strategic self-transformation (Leary, 1995; Schlenker, 1980). We can see this in Chloe's dialogue below about her increasing fear of interpersonal rejection and/or abandonment, despite her apparent trust in her partner's unconditional love (also see table 2 for the friendship context):

I have been really stressed for the last couple of weeks and my skin is really terrible...I probably go back to kind of doing my make-up in the bathroom... But literally there is no reflection on him [my partner] because he is really not superficial. It's almost not fair of me to say this, but my own insecurity. What if he leaves me because I'm not pretty?

This quote also highlights the instability of perceived self-worth or positive self-image (Crocker \& Wolfe, 2001) in influencing which goal to pursue and which self to be and present in intimate relationships. Relationship dissolution can occur when consumers fail to maintain desired impressions, often resulting in emotional strain and ill-wellbeing (Baumeister \& Leary, 1995). This explains why in the face of the fear of increasing social exclusion, people are found to spend and consume strategically in pursuit of affiliation (Mead, Baumeister, Stillman, Rawn, \& Vohs, 2011; Wan, Xu, \& Ding, 2014). We find this is particularly relevant for the participants who frequently expressed insecurity about self-worth and fear of self-disclosure in their interview conversations (see table 4 for more details on 
Chloe and Emma). For these women, they appear to often experience conflicts and debates within the self about which self to present, as they juggle between beliefs of unconditional love and that of self-worth. This is reflected in Emma's conflicting accounts about her makeup use for self-presentation:

E: if I am literally just staying in the house I won't put make-up on because one, I think it's a waste of money, because no one is going to see me well you know my boyfriend will see me but I obviously don't care (laughter) and two, it's not very good for your skin to always have make-up on.

I: Could you tell me more about that you don't care about your boyfriend?

E: I do care like if I did have a really big spot on my face I would cover it up.

Here, we see how Emma's perceived interpersonal context changed from being secure to being preoccupied, and how this change influenced her to pursue the goal of prevention instead of that of intimacy. Despite recounting the benefits linked to not wearing make-up, Emma reports her willingness to sacrifice these benefits if she felt increasingly insecure about her perceived self-flaws. In admitting this, however, Emma then immediately states, "It's just like that feeling of he is with you, he is seeing me looking all sorts... when I have got no make-up on and he still saw things (spots and blemishes), obviously still looks at me and thinks "oh, she looks nice"." These conflicting statements in Emma's dialogue, we argue, to an extent point to the tension she experienced in coming to terms with the necessity for personal adornment or self-disclosure in the relationship, as she deliberates between the pursuit of intimacy and that of prevention.

\subsubsection{Tensions in pursuit of prevention}

Chloe talks about how being mixed-race is a source of her insecurity and drives her personal adornment use to focus on self-concealment: 
I always feel like a bit of outside the world, how I look is right, but my current boyfriend really loves me for the person that I am. I often wear extensions and I recently took them out and he thinks it suits me much better having my natural curly hair but now I'm so used to conforming and having straight hair. I almost can't do it whereas he is helping me because he likes the natural me. But I now don't feel comfortable without it all on.

In contrast to the goal of intimacy that situates the unadorned self as the authentic self (i.e., this is me), participants who pursue the prevention goal are found to experience their adorned self in the main as the inauthentic self (i.e., this is not me). The adorned self here appears to be what Chloe calls a "front" to hide behind in social interactions; something they use to conceal their perceived negative self. Chloe defines her real, natural self: "The real me, just like I just came back from the gym... My hair is afro out, my skin is completely dry, I've got blemishes everywhere ...And I'm just completely comfortable. No one can see me."

Using personal adornment to conceal perceived self-flaws, however, often comes at the price of increasing physical and/or emotional exhaustion (Liu et al., 2016), as Chloe later says, "I would love to be a bit more confident and a bit more like proud of who I was and how I look". The tension here is that while Chloe feels safe with her adorned self in enabling her to prevent interpersonal rejection and/or abandonment, she seems to concurrently experience deep frustration within the self. This is because self-disclosure is regarded as a defining characteristic of a close relationship. In situations where self-disclosure is not achieved, it could undermine the degree of perceived intimacy between parties.

\subsection{In a fearful-avoidant interpersonal context}

\subsubsection{The performance goal}

The goal of performance (Figure 2, bottom left) emerged from a combination of participants' negative self- and negative other- images (i.e., the fearful-avoidance interpersonal context). 
This combination appears to drive our participants to concentrate on ought performances that help foster impressions that are likely to be positively evaluated by the target audience and thus acquire specific interpersonal rewards. Importantly, the performance in this case is underpinned by one's persistent efforts to engage in socially strategic self-transformation aimed at avoiding shame and seeking social approval. Central to our research context, physical appearance constitutes another potential source of stigma, because the stigma of culturally defined "ugliness" can potentially problematize an individual's identity as neither a valued nor a functional member of society (Foucault, 1979; Lewis, 1995). Zoe expresses her consciousness of the sociocultural script of how she should look:

Obviously there were a lot of advertisements in the society at the moment, emphasizing on the looks...so everyone is like keeping up appearances...It is a pressure because sometimes you feel like you just want to be yourself but you can't.

Like Zoe, many of our participants seem to experience their unadorned self as a spoilt, flawed identity and appear to hold themselves responsible for satisfying a culturally valued presentation of the self (Üstüner \& Holt, 2007). Giddens (1991) argues that shame rather than guilt tends to dominate people's self-experiences due to the increasing contemporary focus on the visible aspects of self, that is, the body. Notably, this sense of shame is often experienced when the individual accepts a stigmatized identity as part of the self (Adkins \& Ozanne, 2005; Goffman, 1963). To avoid feeling inadequate, our participants often engage in constant body surveillance through which they attempt to mediate the potential stigma of not “keeping up appearances” (Fredrickson \& Roberts, 1997). Importantly, we notice such a need to "keep up appearances" appears to be particularly prominent during relationship instability (Huang \& Yu, 2000; Øverup \& Neighbors, 2016), as Sophia describes: "Because he [my boyfriend at the time] was going out clubbing and because I wanted to seem more attractive 
to him and that's probably why I was wearing more make-up to make myself appealing which you do and you don't realize at the time that you were with the wrong person".

Yet, not all participants who pursue the goal of performance see themselves as vulnerable to the sociocultural script of how one should look. There is a strong focus in Kylie's conversations on "being in control" by using her cosmetics as a way of strengthening her desired social positions rather than as a "camouflage" to conceal perceived self-flaws. Kylie defines what she means by control:

For me, cosmetics are just control... when you've got a board meeting and you want them to take you seriously, I'll put on my powder and my concealer...my face is like a blank canvas... They gotta focus on what I'm saying to them...If I'm meeting a new guy and I want him to listen, then I'll place a little bit of emphasis on my eyes...

Here, we see how Kylie varies her self-presentation through make-up use to actively manage and set clear boundaries between her different relational selves. However, as we will argue next, depending on the underlying goal of adorning the self, our participants appear to experience different tensions in their self-presentation endeavors.

\subsubsection{Tensions in pursuit of performance}

When personal adornment is aimed at self-enhancement, our participants are noted to experience both the adorned and the unadorned self as the authentic self (this is me), as Kylie states, "I'm just like well at the end of the day why settle to be the person who just rolls out of the bed when there are things that are within your control like putting a bit of make-up on would make you be an A grade version of you. You're still you, just better." However, the subtle tension here is that personal adornment becomes the prerequisite for self-enhancement and the resultant positive self-experience. On the other hand, similar to the prevention goal, when the body surveillance is intended for self-concealment, they tend to experience their adorned self as "camouflage" and as the inauthentic self (this is not me). Kylie illustrates how 
tensions intensified within the self when her intended make-up use changed from selfenhancement to self-concealment:

Because you don't like the way you look [when my face is breaking out], you try to hide it, hence the make-up. To me, it doesn't feel natural to have to spend a lot of time staring at myself in the mirror to feel confident enough to go out. So when I'm doing it, I'm like inwardly cursing my face for doing this but I'm also pissed off at myself that I even care (laughter) so just a lot of self-loathing going on.

While Kylie still seems to recognize her unadorned self as me, the unadorned self for many participants becomes something they claim as "abnormal" or "disgusting", as Aubrey admits, "I feel disgusting without it (make-up) on...I am me when I have got make-up on." The unadorned self becomes something they feel ashamed about, something they deny as representing who they are, and this often undermines how they behave in social interactions as a result (Lewis, 1995; Liu et al., 2012).

\subsection{In a dismissing-avoidant interpersonal context}

\subsubsection{The authenticity goal}

Finally, the goal of authenticity (Figure 2, upper left) surfaces in guiding participants' selfpresentation when they experience a combination of positive self-image and negative otherimage (i.e., the dismissing-avoidance interpersonal context). We find that participants' selfpresentation in this case is focused on achieving autonomy and a subjective sense of being true to the self (i.e., "felt authenticity"). There is much debate over the term authenticity, which has proved a complex concept to define (Erickson, 1995; Leary, 2003). Within this study, it is used to refer to how participants choose to present a self that is in line with their natural inclinations (i.e., authentic self-expression), despite knowing that in presenting that self they could face social disapproval, rejection and/or some penalty. Kylie emphasizes the importance of exhibiting her natural inclinations in everyday life: 
I'm exactly the same [when it comes to dating]. If I'm at home...you'll see me with no make-up on. If I'm going out meeting friends...you'll see me with make-up on. I'd not change at all...I think to myself "well you've seen me looking my social best, if you still fancy me when I'm walking into the shop in the morning to buy my bread then by all means, come over and talk", probably won't!

Concealing the self for interpersonal gains often results in psychological tensions, since one is likely to assume that acceptance or relationship wellbeing results from impression management efforts rather than from an honest view of the self (Leary, 2003). In the above quote, we see the emphasis Kylie placed on demonstrating her everyday natural inclinations in establishing a genuine romance and preventing the superficiality often associated with physical attraction. Jill's description below further highlights how heightened positive selfimage induced in one relationship can drive one to pursue authenticity in her general interpersonal exchanges. Having admitted, "having a good image is the key to everything", Jill then talks about how appealing to others becomes unnecessary when she became pregnant: "It's like almost this is what I always wanted [having a baby]. I don't care about how I look. I'm so happy." Yet, such heightened positive self-image can be short-lived due to the tensions that are often involved in disclosing the self for authenticity, as we discuss below.

\subsubsection{Tensions in pursuit of authenticity}

We find participants who assume the goal of authenticity tend to present a less adorned self, which they view as the authentic self (this is me) (at least in the Western context). This felt sense of authenticity in social interactions has been noted to generate a sense of fulfillment (Rogers, 1961), positive mood (Lenton, Bruder, Slabu, \& Sedikides, 2013) as well as optimal self-esteem (Kernis, 2003). This is particularly the case for women because of gendered expectations that they be dependent and self-sacrificing to please others (Miller, 1986). Yet, the internalization of the values or views of other people clearly makes authenticity difficult 
to express and causes internal contradictions (Leary, 2003; Wood, Linley, Maltby, Baliousis, \& Joseph, 2008). This might explain why Kylie often gives apparently contradictory and inconsistent reports about her experiences of authentic self-expression:

Luckily enough, I'm not that sort of person that would feel like horrendously insecure in terms of not wearing make-up...

No one wants to kind of feel they're apart from everyone...It's like this person has made an effort to conform to a standard [getting dressed up etc.] and you look like a tramp in the street (laughter)...

If you can't go out with no make-up on, it's a bit like: what are you hiding? so that's kind of my view on it. I'm quite happy [not to wear make-up when I am out] I'm not that kind...

Past research on the interpersonal aspect of self-presentation (Leary \& Downs, 1995;

Leary, Tambor, Terdal, \& Downs, 1995) proposes that people who believe they are inherently acceptable tend to engage in self-expression that trades social acceptance for authenticity. Yet, with enough evidence to the contrary, such people will start to act to improve their standing in the eyes of others for social approval (Leary, 2003).

\section{Discussion}

Our study focuses on exploring consumers' deliberations about self-presenting when faced with varying interpersonal encounters. To this end, we examined (1) what are the goals consumers pursue in relation to their self-presentations? And, (2) what are the tensions consumers might experience in pursuing these goals as they respond to distinct interpersonal contexts? Scholars have criticized the prevailing tendency among social psychologists that treat intrapsychic and interpersonal influences as separate, non-interacting entities when studying how people create desired social images or identities (Tetlock \& Manstead, 1985; Vohs et al., 2005). Our findings respond to Baumeister's (2010) call to treat these influences 
as linked in impacting on individuals' self-presentation efforts. In our analysis, we used AT or Bartholomew and Horowitz's adult attachment model (1991) more specifically, to illuminate our understanding of consumers' internal debates in coming to terms with which goals to pursue and which self to be and present when faced with varied interpersonal contexts (i.e., secure, preoccupied, fearful-avoidant and dismissing-avoidant). We found that consumers vary their goals to achieve a general sense of felt security depending on which interpersonal context they found themselves in. Four types of goal-pursuit were identified, corresponding to each interpersonal context highlighted above: intimacy, prevention, performance and authenticity. While achieving the goals of intimacy and authenticity requires consumers to focus on cultivating a more authentic self-expression (i.e., more willingness to disclose the unadorned self or perceived self-flaws, as treated in this study), socially strategic self-transformation (i.e., greater presentation of the ought self with an emphasis on self-concealment or self-enhancement) is seen as essential to achieve the prevention and performance goals. Note that we do not claim that the range of interpersonal contexts and the associated goal-purusits we identified will influence consumer behavior in all interpersonal exchanges, nor that this is an exhaustive list. However, we argue that to the extent that a particular interpersonal context becomes more salient, certain goals tend to ensue to guide the kind of consumer behavior deemed necessary to achieve that goal.

Importantly, past research has shown that consumers often experience tension between "who I want to be" and "who I should be", when negotiating self-presentation (Larsen et al., 2014; Murray, 2002; Ruvio \& Belk, 2018; Thompson \& Haytko, 1997). We add to this stream of research by identifying the tensions consumers experience in coming to terms with which goal to pursue, who to be and which self to present in distinct interpersonal contexts (see table 3 for a summary). Specifically, we highlight the expressive and transformative elements that may underpin consumers' consumption deliberations in response to distinct 
interpersonal contexts. For example, in seeking to attain the goal of intimacy or authenticity, we find that our participants are generally happy to focus on cultivating authentic selfexpression that may possibly reveal perceived self-flaws or challenge the status quo. However, this is only when the self-presentation does not over-ride their fundamental need to belong (see also Baumeister \& Leary, (1995) on the need to belong). On the occasions when they sense that the authentic self-expression may pose a stronger threat to their sense of belongingness, the women in our study then strategically utilize personal adornment to aid self-enhancement or concealment in the service of relationship acquisition or affirmation. This perhaps helps explain why many of our participants in their interview dialogues gave conflicting accounts with respect to how they adorn the self in a given relationship.

Moreover, in developing our understanding of the tensions consumers experience between their sense of self and goal-pursuits, our findings further contribute to the growing literature on the important role of self-transformation in resisting aspects of the undesired self (Ahuvia, 2005; Bahl \& Milne, 2010; Liu et al., 2016; Ogilvie, 1987; Ruvio \& Belk, 2018). For example, the performance goal emphasizes the importance of self-transformation in avoiding shame and obtaining social approval. We find through our participants' experiences that when their use of personal adornment is aimed at concealing 'who I am' to achieve selftransformation, these women often experience tensions within the self (e.g., to hide perceived self-flaws vs. self-loathing as in the case of Kylie). In contrast, when the transformed/adorned self is perceived as enhancing 'who I am', personal adornment that aids self-transformation is experienced more as a means to control or strengthen desired social positions. Yet, while self-transformation enables these women to feel in better control of social situations, personal adornment becomes the prerequisite for securing desired social positions and positive selfexperiences. These findings yield important implications for the long-standing, ongoing debate on how sincere the presented self is (Goffman, 1959; Leary, 1995; Ruvio \& Belk, 
2018; Tseëlon, 1992) by demonstrating the value-laden nature of self-transformation, and its intricate relationship with women consumers' beliefs about the self and others in a given relationship.

Taken together, it can be tentatively concluded that the range of goals our participants pursue through their self-presentation offers them the means to quickly respond to perceived changing patterns of interpersonal exchanges. This then helps them maintain or develop a relationship while continuing to defend a psychological sense of felt security in situations (Murray, Holmes, \& Griffin, 2000; Pietromonaco \& Barrett, 2000). For example, whereas the intimacy goal advocates self-disclosure to increase consumers' felt security in a relationship, the prevention goal urges self-concealment to achieve this. The inability to draw on consumption (or personal adornment in this study) to present a self that aids goal-pursuits can lead to profound distress and anxiety (also see Üstüner \& Holt, 2007's work on "the shattered self"). Therefore, we argue, consumer agency is enabled when the consumer could engage in consumption that helped cultivate various self-presentations. These self-presentations act as solutions to fulfill their specific goal-pursuits in interpersonal interactions. Consumer agency is, however, concurrently experienced as constrained due to the tensions that consumers must tolerate in cultivating a given self-presentation to achieve the particular goal. Whereas a general sense of felt security is achieved through specific self-presentation/consumption behaviors, the tensions consumers experience in engaging in these behaviors also work to undermine or compromise the felt security.

\section{Implications for attachment theory, consumer research, and limitations of the study}

Having utilized AT to illuminate our findings, our study also offers important implications for advancing understandings of research relevant to AT. Global attachment styles are largely stable, although consumers do also have relationship-specific orientations (Mikulincer \& Shaver, 2016; Nguyen \& Munch, 2011, 2014). Individuals' attachment styles may also be 
updated as they respond to ongoing interpersonal experiences (Fraley et al., 2011; Gillath et al., 2016; Stern et al., 2018). Our findings add to this stream of research by revealing preliminary, but nonetheless strong, indications of how an individual's security of attachment may be revised and developed over time within specific relationships. It depends not only on her overall sense of self-worth but also on the perceived situational affordances (sense of belongingness in this case) at the time. These, we argue, are reflected in the changing goals to achieve in a given relationship and how our participants vary their use of personal adornment to achieve these goals (e.g., see table 4).

Further, consumer research drawing on AT has suggested that people may be strongly attached to and derive satisfaction from their brand relationships as a result of perceived deficits in their personal relationships (Thomson et al., 2012; Whelan et al., 2016). Our findings suggest, apart from seeking to form a marketplace relationship to compensate for the perceived shortcomings in personal relationships, insecure consumers may also rely on everyday consumption (e.g., personal adornment in the present research) to regulate the space between self and others through which they seek to tackle perceived relationship shortcomings (also see Øverup \& Neighbors, 2016).

Moreover, Thomson, Whelan, and Johnson (2012) found that while fearful consumers are likely to invest more into brand relationships and thus are more likely to become the most profitable and vocal advocates of a brand, they may also become its worst disparagers if the relationship ends. As such, Thomson et al. (2010) call for research into the types of products that might be more attractive to fearful consumers. Firms should therefore be more vigilant about these. Mende, Bolton and Bitner's (2013) study of health insurance found the majority of their participants were marked by a secure attachment. This is in line with earlier research that found that the majority of people's attachment orientations are closer to the positive end of the attachment anxiety and avoidance dimensions (Feeney \& Noller, 1990; Hazan \& 
Shaver, 1987). In contrast to these findings, however, we found our participants' consumption deliberations seem to be mainly driven by a fearful-avoidant attachment style. This is perhaps not surprising as our participants are consumers who regularly use make-up and engage in personal adornment activities to enhance or transform their perceived self (also see Fredrickson \& Roberts, 1997; Liu et al., 2012; Strelan \& Hargreaves, 2005). We, therefore, tentatively suggest that appearance-related product categories (e.g., cosmetics, fashion clothing etc.) may attract fearful consumers to a greater extent, especially those emphasizing self-concealment (e.g., covering up self-flaws).

Finally, gender clearly remains a powerful ideological force that produces, legitimates and constrains our negotiations regarding what to consume? how to act? and who to be? (West \& Zimmerman, 1987). An obvious and immediate extension of this study is, thus, to explore how our findings may apply to or require adaptation to men's lived experiences. To what extent do men, compared with women, experience tension(s) between their sense of self and goal-pursuits? Our study only looked at women, who are traditionally seen as focused on others' needs in their social worlds (Thompson, 1996). Men, in contrast, are often portrayed (perhaps unfairly) as more instrumental - and thus the potential relevance of interpersonal contexts in influencing goal-pursuits and consumption experiences might differ significantly for them.

\section{References}

Adkins, N. R., \& Ozanne, J. L. (2005). The low literate consumer. Journal of Consumer Research, 32(1), 93-105.

Ahuvia, A. C. (2005). Beyond the extended self: Loved objects and consumers' identity narratives. Journal of Consumer Research, 32(1), 171-184.

Ainsworth, M. D. S., \& Bowlby, J. (1991). An ethological approach to personality development. American Psychologist, 46(4), 333-341. 
Arndt, J., Solomon, S., Kasser, T., \& Sheldon, K. M. (2004). The urge to splurge: A terror management account of materialism and consumer behavior. Journal of Consumer Psychology, 14(3), 198-212.

Askegaard, S., Gertsen, M. C., \& Langer, R. (2002). The body consumed: Reflexivity and cosmetic surgery. Psychology \& Marketing, 19(10), 793-812.

Askegaard, S., \& Linnet, J. T. (2011). Towards an Epistemology of Consumer Culture Theory: Phenomenology and the Context of Context. Marketing Theory, 11(4), 381404.

Bahl, S., \& Milne, G. R. (2010). Talking to ourselves: A dialogical exploration of consumption experiences. Journal of Consumer Research, 37(1), 176-195.

Banai, E., Mikulincer, M., \& Shaver, P. R. (2005). "Selfobject" Needs in Kohut's Self Psychology: Links With Attachment, Self-Cohesion, Affect Regulation, and Adjustment. Psychoanalytic Psychology, 22(2), 224-260.

Bartholomew, K. (1990). Avoidance of intimacy: An attachment perspective. Journal of Social and Personal Relationships, 7(2), 147-178.

Bartholomew, K., \& Horowitz, L. M. (1991). Attachment styles among young adults: a test of a four-category model. Journal of Personality and Social Psychology, 61(2), 226244.

Baumeister, R. F. (2010). The self. In R. F. Baumeister \& E. J. Finkel (Eds.), Advanced social psychology: The state of the science (pp. 139-175). New York, NY: Oxford University Press.

Baumeister, R. F., \& Leary, M. R. (1995). The need to belong: desire for interpersonal attachments as a fundamental human motivation. Psychological Bulletin, 117(3), 497529.

Belk, R. W. (2003). Shoes and self. Advances in Consumer Research, 30, 27-33. 
Belk, R. W., \& Costa, J. A. (1998). The mountain man myth: A contemporary consuming fantasy. Journal of Consumer Research, 25(3), 218-240.

Bowlby, J. (1973). Attachment and loss: Vol. 2. Separation. New York: Basic Books.

Brennan, K. A., \& Bosson, J. K. (1998). Attachment-style differences in attitudes toward and reactions to feedback from romantic partners: An exploration of the relational bases of self-esteem. Personality and Social Psychology Bulletin, 24(7), 699-714.

Chopik, W. J., Edelstein, R. S., \& Fraley, R. C. (2013). From the cradle to the grave: Age differences in attachment from early adulthood to old age. Journal of Personality, 81(2), 171-183.

Collins, N. L. (1996). Working models of attachment: Implications for explanation, emotion, and behavior. Journal of Personality and Social Psychology, 71(4), 810-832.

Collins, N. L., \& Read, S. J. (1990). Adult attachment, working models, and relationship quality in dating couples. Journal of Personality and Social Psychology, 58(4), 644663.

Collins, N. L., \& Read, S. J. (1994). Cognitive representations of attachment: The structure and function of working models. In K. Bartholomew \& D. Perlman (Eds.), Advances in Personal Relationships (Vol. 5, pp. 53-90). Philadelphia: Jessica Kingsley.

Crocker, J., \& Wolfe, C. T. (2001). Contingencies of self-worth. Psychological Review, $108(3), 593-623$.

David, M. E. (2016). The role of attachment style in shaping consumer preferences for products shown in advertisements that depict consensus claims. Journal of Advertising, 45(2), 227-243.

Epstein, S. (1992). Coping ability, negative self-evaluation, and overgeneralization: Experiment and theory. Journal of Personality and Social Psychology, 62(5), 826-836. 
Erickson, R. J. (1995). The importance of authenticity for self and society. Symbolic Interaction, 18(2), 121-144.

Feeney, B. C., Van Vleet, M., Jakubiak, B., Simpson, J., \& Rholes, W. (2015). An attachment theoretical perspective on optimal dependence in close relationships. In J. A. Simpson \& W. S. Rholes (Eds.), Attachment theory and research: New directions and emerging themes. . New York, London: Guilford.

Feeney, J. A., \& Noller, P. (1990). Attachment style as a predictor of adult romantic relationships. Journal of Personality and Social Psychology, 58(2), 281-291.

Firat, A. F., \& Venkatesh, A. (1995). Liberatory postmodernism and the reenchantment of consumption. Journal of Consumer Research, 22(3), 239-267.

Foucault, M. (1979). Discipline and Punish. New York: Pantheon.

Fournier, S., \& Alvarez, C. (2012). Brands as relationship partners: Warmth, competence, and in-between. Journal of Consumer Psychology, 22(3), 177-185.

Fraley, R. C., Hudson, N. W., Heffernan, M. E., \& Segal, N. (2015). Are adult attachment styles categorical or dimensional? A taxometric analysis of general and relationshipspecific attachment orientations. Journal of Personality and Social Psychology, 109(2), 354-368.

Fraley, R. C., \& Roberts, B. W. (2005). Patterns of continuity: a dynamic model for conceptualizing the stability of individual differences in psychological constructs across the life course. Psychological Review, 112(1), 60-74.

Fraley, R. C., Vicary, A. M., Brumbaugh, C. C., \& Roisman, G. I. (2011). Patterns of stability in adult attachment: an empirical test of two models of continuity and change. Journal of Personality and Social Psychology, 101(5), 974-992.

Fredrickson, B. L., \& Roberts, T.-A. A. (1997). Objectification theory. Psychology of Women Quarterly, 21(2), 173-206. 
Giddens, A. (1991). Modernity and self-identity: Self and society in the late modern age. Cambridge Polity Press.

Gillath, O., Karantzas, G. C., \& Fraley, R. C. (2016). How stable are attachment style in adulthood Adult attachment: A concise introduction to theory and research (pp. 129158). Elsevier: Academic Press.

Goffman, E. (1959). The presentation of self in everyday life. New York Anchor Press, Doubleday.

Goffman, E. (1963). Stigma: Notes on the management of spoiled identity. New Jersey: Prentice-Hall Inc.

Hazan, C., \& Shaver, P. (1987). Romantic love conceptualized as an attachment process. Journal of Personality and Social Psychology, 52(3), 511-524.

Huang, M.-H., \& Yu, S. (2000). Gifts in a romantic relationship: A survival analysis. Journal of Consumer Psychology, 9(3), 179-188.

Kernis, M. H. (2003). Toward a conceptualization of optimal self-esteem. Psychological Inquiry, 14(1), 1-26.

Kirkpatrick, L. A., \& Hazan, C. (1994). Attachment styles and close relationships: A fouryear prospective study. Personal Relationships, 1(2), 123-142.

Klein, J. G., Lowrey, T. M., \& Otnes, C. C. (2015). Identity-based motivations and anticipated reckoning: Contributions to gift-giving theory from an identity-stripping context. Journal of Consumer Psychology, 25(3), 431-448.

La Guardia, J. G., Ryan, R. M., Couchman, C. E., \& Deci, E. L. (2000). Within-person variation in security of attachment: a self-determination theory perspective on attachment, need fulfillment, and well-being. Journal of Personality and Social Psychology, 79(3), 367-384. 
Larsen, G., Patterson, M., \& Markham, L. (2014). A Deviant Art: Tattoo-Related Stigma in an Era of Commodification. Psychology \& Marketing, 31(8), 670-681.

Laurenceau, J.-P., Barrett, L. F., \& Pietromonaco, P. R. (1998). Intimacy as an interpersonal process: the importance of self-disclosure, partner disclosure, and perceived partner responsiveness in interpersonal exchanges. Journal of Personality and Social Psychology, 74(5), 1238-1251.

Leary, M. R. (1995). Self-presentation: Impression management and interpersonal behavior. Madison, WI: Brown \& Benchmark Publishers.

Leary, M. R. (2003). Interpersonal aspects of optimal self-esteem and the authentic self. Psychological Inquiry, 14(1), 52-54.

Leary, M. R., \& Allen, A. B. (2011). Self-presentational persona: simultaneous management of multiple impressions. Journal of Personality and Social Psychology, 101(5), 10331049.

Leary, M. R., \& Downs, D. L. (1995). Interpersonal functions of the self-esteem motive: The self-esteem system as a sociometer In M.Kemis (Ed.), Efficacy, agency, and selfesteem (pp. 123-144). New York: Plenum.

Leary, M. R., Tambor, E. S., Terdal, S. K., \& Downs, D. L. (1995). Self-esteem as an interpersonal monitor: The sociometer hypothesis. Journal of Personality and Social Psychology, 68(3), 518.

Lemay Jr, E. P., Clark, M. S., \& Greenberg, A. (2010). What is beautiful is good because what is beautiful is desired: Physical attractiveness stereotyping as projection of interpersonal goals. Personality and Social Psychology Bulletin, 36(3), 339-353.

Lenton, A. P., Bruder, M., Slabu, L., \& Sedikides, C. (2013). How does “being real” feel? The experience of state authenticity. Journal of Personality, 81(3), 276-289.

Lewis, M. (1995). Shame: The exposed self. New York, N.Y.: Free Press. 
Liu, C., Keeling, D., \& Hogg, M. (2012). The Unspoken Truth: A Phenomenological Study of Changes in Women's Sense of Self and the Intimate Relationship with Cosmetics Consumption. Research in Consumer Behavior, 14, 89-107.

Liu, C., Keeling, D. I., \& Hogg, M. K. (2016). Strategy narratives and wellbeing challenges: the role of everyday self-presentation. Journal of Business Research, 69(1), 234-243.

Luborsky, L., \& Crits-Christoph, P. (1998). Understanding transference: The core conflictual relationship theme method. Washington, DC: American Psychological Association.

Main, M., Kaplan, N., \& Cassidy, J. (Eds.). (1985). Security in infancy, childhood, and adulthood: A move to the level of representation (Vol. 50 (1-2, Serial No. 209)).

Mashek, D. J., \& Aron, A. (Eds.). (2004). Handbook of closeness and intimacy. Mahwah, NJ: Lawrence Erlbaum Associates.

McAlexander, J. H., \& Schouten, J. W. (1989). Hairstyle changes as transition markers. Sociology and Social Research, 74(1), 58-62.

Mead, N. L., Baumeister, R. F., Stillman, T. F., Rawn, C. D., \& Vohs, K. D. (2011). Social exclusion causes people to spend and consume strategically in the service of affiliation. Journal of consumer research, 37(5), 902-919.

Mende, M., Bolton, R. N., \& Bitner, M. J. (2013). Decoding customer-firm relationships: how attachment styles help explain customers' preferences for closeness, repurchase intentions, and changes in relationship breadth. Journal of Marketing Research, 50(1), $125-142$.

Mikulincer, M., \& Shaver, P. R. (2016). Attachment in adulthood: Structure, dynamics, and change (second edition). New York: Guilford Press.

Miller, J. B. (1986). Toward a new psychology of women. Boston: Beacon Press. 
Morrison, T. L., Goodlin-Jones, B. L., \& Urquiza, A. J. (1997). Attachment and the representation of intimate relationships in adulthood. The Journal of Psychology, 131(1), 57-71.

Murray, J. B. (2002). The Politics of Consumption: A Re-Inquiry on Thompson and Haytko's (1997) “Speaking of Fashion”. Journal of Consumer Research, 29(3), 427-440.

Murray, S. L., Holmes, J. G., \& Griffin, D. W. (2000). Self-esteem and the quest for felt security: how perceived regard regulates attachment processes. Journal of Personality and Social Psychology, 78(3), 478-498.

Nguyen, H. P., \& Munch, J. M. (2011). Romantic gift giving as chore or pleasure: The effects of attachment orientations on gift giving perceptions. Journal of Business Research, 64(2), 113-118.

Nguyen, H. P., \& Munch, J. M. (2014). The moderating role of gift recipients' attachment orientations on givers' gift-giving perceptions. Journal of Consumer Behaviour, 13(5), 373-382.

Note, K. (2016). Cosmetics \& Fragrances: Market Reports (pp. 1-100).

Ogilvie, D. M. (1987). The undesired self: A neglected variable in personality research. Journal of Personality and Social Psychology, 52(2), 379-385.

Øverup, C. S., \& Neighbors, C. (2016). Self-presentation as a function of perceived closeness and trust with romantic partners, friends, and acquaintances. The Journal of Social Psychology, 156(6), 630-647.

Paulssen, M. (2009). Attachment orientations in business-to-business relationships. Psychology \& Marketing, 26(6), 507-533.

Pierce, T., \& Lydon, J. E. (2001). Global and specific relational models in the experience of social interactions. Journal of Personality and Social Psychology, 80(4), 613-631. 
Pietromonaco, P. R., \& Barrett, L. F. (2000). The internal working models concept: What do we really know about the self in relation to others? Review of General Psychology, $4(2), 155-175$.

Rabinovich, M., \& Kacen, L. (2013). Qualitative coding methodology for interpersonal study. Psychoanalytic Psychology, 30(2), 210-231.

Ren, D., Arriaga, X. B., \& Mahan, E. R. (2017). Attachment insecurity and perceived importance of relational features. Journal of Social and Personal Relationships, 34(4), 446-466.

Rindfleisch, A., Burroughs, J. E., \& Wong, N. (2009). The safety of objects: Materialism, existential insecurity, and brand connection. Journal of Consumer Research, 36(1), 116.

Rogers, C. (1961). On becoming a person: A therapist's view of psychotherapy. Boston, MA: Houghton Mifflin Harcourt.

Ruth, J. A., Otnes, C. C., \& Brunel, F. F. (1999). Gift receipt and the reformulation of interpersonal relationships. Journal of Consumer Research, 25(4), 385-402.

Ruvio, A., \& Belk, R. (2018). Strategies of the extended self: The role of possessions in transpeople's conflicted selves. Journal of Business Research, 88(July), 102-110.

Sbarra, D. A., \& Hazan, C. (2008). Coregulation, dysregulation, self-regulation: An integrative analysis and empirical agenda for understanding adult attachment, separation, loss, and recovery. Personality and Social Psychology Review, 12(2), 141167.

Schlenker, B. R. (1980). Impression management: The self-concept, social identity, and interpersonal relations. Monterey, CA: Brooks/Cole

Schouten, J. W. (1991). Selves in transition: Symbolic consumption in personal rites of passage and identity reconstruction. Journal of Consumer Research, 17(4), 412-425. 
Scott, L. M. (2006). Fresh lipstick: Redressing fashion and feminism. New York: Palgrave Macmillan.

Seregina, A., \& Weijo, H. (2017). Play at Any Cost: How Cosplayers Produce and Sustain Their Ludic Communal Consumption Experiences. Journal of Consumer Research, 44(1), 139-159

Sherry, J. F. (1983). Gift giving in anthropological perspective. Journal of Consumer Research, 10(2), 157-168.

Snyder, M. (1987). Public appearances, private realities: The psychology of self-monitoring. New York, NY, US: WH Freeman/Times Books/Henry Holt \& Co.

Stern, J. A., Fraley, R. C., Jones, J. D., Gross, J. T., Shaver, P. R., \& Cassidy, J. (2018). Developmental processes across the first two years of parenthood: Stability and change in adult attachment style. Developmental Psychology, 54(5), 975-988.

Strelan, P., \& Hargreaves, D. (2005). Women who objectify other women: The vicious circle of objectification? Sex Roles, 52(9-10), 707-712.

Swaminathan, V., Stilley, K. M., \& Ahluwalia, R. (2009). When brand personality matters: The moderating role of attachment styles. Journal of Consumer Research, 35(6), 9851002.

Tetlock, P. E., \& Manstead, A. S. (1985). Impression management versus intrapsychic explanations in social psychology: A useful dichotomy? Psychological Review, 92(1), $59-77$.

Thompson, C. J. (1996). Caring consumers: gendered consumption meanings and the juggling lifestyle. Journal of Consumer Research, 22(4), 388-407.

Thompson, C. J., \& Haytko, D. L. (1997). Speaking of fashion: consumers' uses of fashion discourses and the appropriation of countervailing cultural meanings. Journal of Consumer Research, 24(1), 15-42. 
Thomson, M., Whelan, J., \& Johnson, A. R. (2012). Why brands should fear fearful consumers: how attachment style predicts retaliation. Journal of Consumer Psychology, 22(2), 289-298.

Tian, K., \& Belk, R. W. (2005). Extended self and possessions in the workplace. Journal of Consumer Research, 32(2), 297-310.

Tseëlon, E. (1992). Is the presented self sincere? Goffman, impression management and the postmodern self. Theory, Culture \& Society, 9(2), 115-128.

Üstüner, T., \& Holt, D. B. (2007). Dominated consumer acculturation: The social construction of poor migrant women's consumer identity projects in a Turkish squatter. Journal of Consumer Research, 34(1), 41-56.

Vohs, K. D., Baumeister, R. F., \& Ciarocco, N. J. (2005). Self-regulation and selfpresentation: regulatory resource depletion impairs impression management and effortful self-presentation depletes regulatory resources. Journal of Personality and Social Psychology, 88(4), 632-657.

Wan, E. W., Xu, J., \& Ding, Y. (2014). To be or not to be unique? The effect of social exclusion on consumer choice. Journal of Consumer Research, 40(6), 1109-1122.

West, C., \& Zimmerman, D. H. (1987). Doing gender. Gender \& Society, 1(2), 125-151. Whelan, J., Johnson, A. R., Marshall, T. C., \& Thomson, M. (2016). Relational domain switching: Interpersonal insecurity predicts the strength and number of marketplace relationships. Psychology \& Marketing, 33(6), 465-479.

Wood, A. M., Linley, P. A., Maltby, J., Baliousis, M., \& Joseph, S. (2008). The authentic personality: A theoretical and empirical conceptualization and the development of the Authenticity Scale. Journal of Counseling Psychology, 55(3), 385-399. 


\section{Figures}

Figure 1: Model of adult attachment (adapted from Bartholomew \& Horowitz, 1991, p. 227)

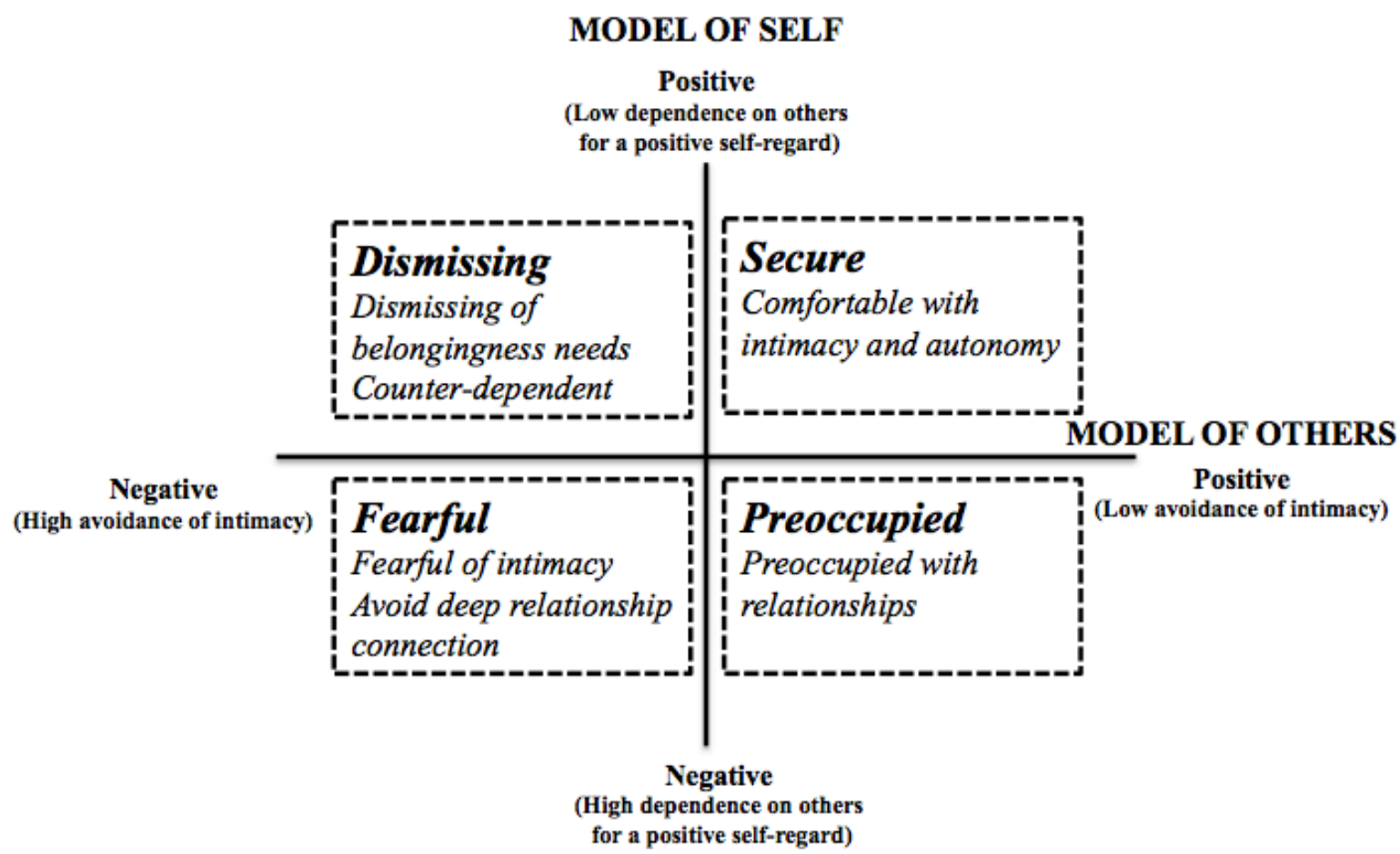

Figure 2: A preliminary framework of the role of interpersonal contexts in influencing

consumers' goal-pursuits and sense of self

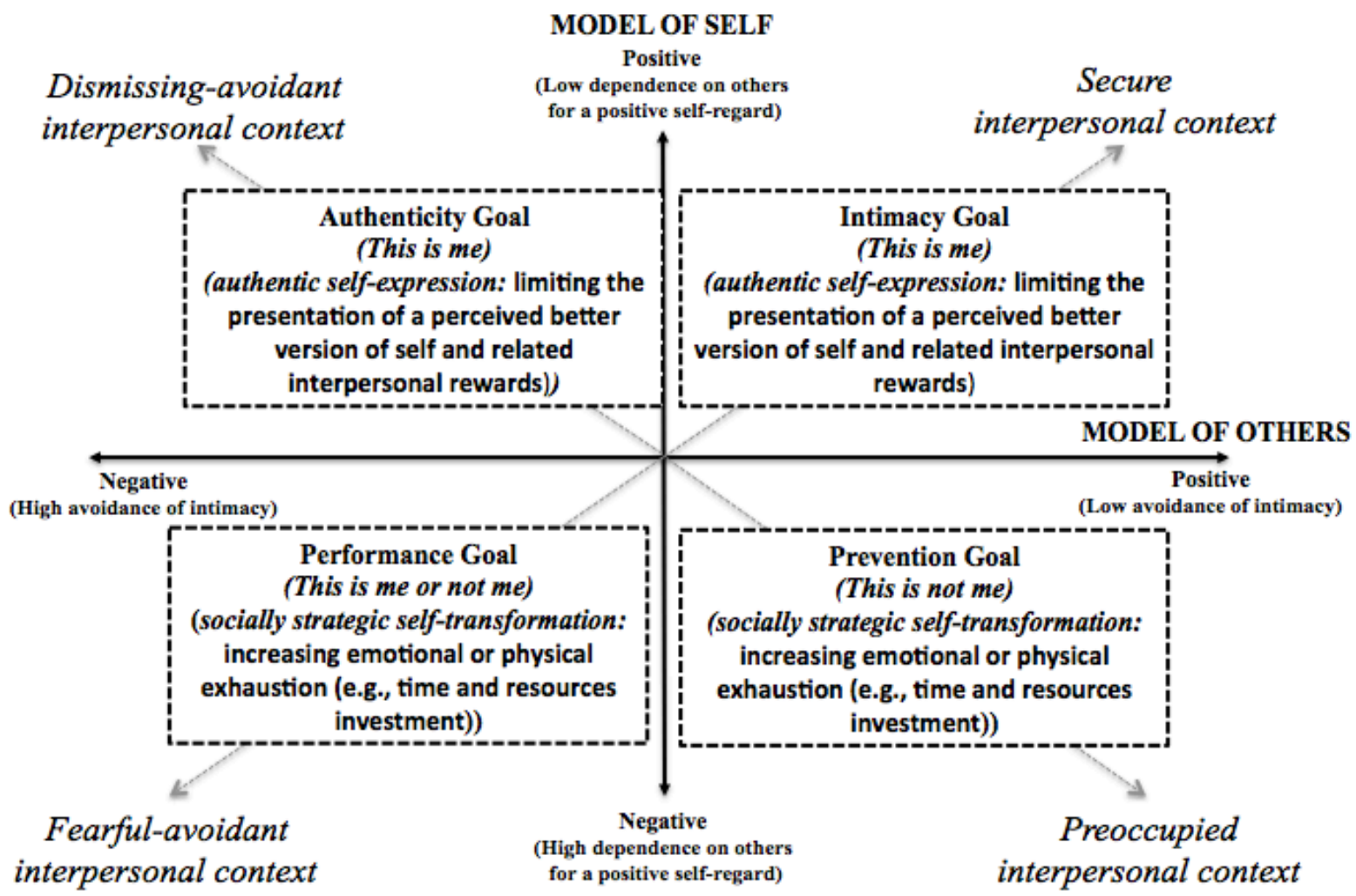


Tables

Table 1: Informants' profile ( $\mathrm{N}=31)$

\begin{tabular}{|c|c|c|c|c|}
\hline Pseudonym & Age & Occupation & Race & Relationship status \\
\hline Sophia & 29 & School art teacher & $\mathrm{C}$ & In a relationship for 3 years \\
\hline Emma & 26 & Fashion trainee buyer & $\mathrm{C}$ & In a relationship for 3 years \\
\hline Olivia & 27 & $\begin{array}{l}\text { Admissions officer and } \\
\text { events assistant }\end{array}$ & $\mathrm{C}$ & Engaged for 6 months \\
\hline Ava & 28 & HR manager & $\mathrm{C}$ & Single \\
\hline Isabella & 27 & Teaching assistant & $\mathrm{M}$ & In a relationship for 7 years \\
\hline Mia & 26 & Researcher & $\mathrm{C}$ & In a relationship for 4 years \\
\hline Zoe & 30 & Investment analyst & $\mathrm{M}$ & Engaged for 2 years \\
\hline Lily & 30 & Auditor & $\mathrm{C}$ & Single \\
\hline Madison & 31 & Accountant & $\mathrm{C}$ & Married for 3 years \\
\hline Chloe & 27 & Communications manager & M & In a relationship for 2 years \\
\hline Charlotte & 24 & Marketing executive & M & In a relationship for 7 years \\
\hline Aubrey & 22 & Assistant administrator & $\mathrm{C}$ & In a relationship for 7 months \\
\hline Avery & 27 & $\begin{array}{l}\text { Social worker (used to } \\
\text { work in Selfridges) }\end{array}$ & $\mathrm{A}$ & In a relationship for 10 years \\
\hline Layla & 29 & Graphic designer & $\mathrm{C}$ & In a relationship for 3 months \\
\hline Harper & 27 & School teacher & $\mathrm{C}$ & In a relationship for 4.5 years \\
\hline Ella & 22 & Legal assistant & $\mathrm{C}$ & In a relationship for 3.5 years \\
\hline Amelia & 19 & Student & $\mathrm{C}$ & In a relationship for 2 years \\
\hline Aria & 30 & $\begin{array}{l}\text { Administrator and a } \\
\text { qualified hair dresser }\end{array}$ & $\mathrm{C}$ & Single parent \\
\hline Kylie & 25 & Accountant & A & Single \\
\hline Grace & 35 & Copywriter & $\mathrm{C}$ & Single \\
\hline Claire & 20 & Receptionist & $\mathrm{C}$ & In a relationship for a year \\
\hline Lucy & 55 & Personal Assistant & $\mathrm{C}$ & $\begin{array}{l}\text { Divorced but engaged at the time } \\
\text { of the interview }\end{array}$ \\
\hline Maria & 55 & Youth worker & $\mathrm{C}$ & Married for 33 years \\
\hline Violet & 61 & Beauty therapist & $\mathrm{C}$ & Married for 40 years \\
\hline Sadie & 52 & $\begin{array}{l}\text { Working part-time in } \\
\text { clothes stores }\end{array}$ & $\mathrm{C}$ & Married for 28 years \\
\hline Skyler & 50 & Business owner & $\mathrm{C}$ & $\begin{array}{l}\text { Married, met her husband since } \\
\text { she was } 18 \text { years old }\end{array}$ \\
\hline Eva & 57 & Cashier for Tesco & $\mathrm{C}$ & Married for 38 years \\
\hline Vivian & 62 & $\begin{array}{l}\text { Retired state agent (used to } \\
\text { work at school too) }\end{array}$ & $\mathrm{C}$ & Married for 32 years \\
\hline Jill & 56 & Administration & $\mathrm{C}$ & Married for 31 years \\
\hline Julia & 59 & Social worker & $\mathrm{A}$ & Divorced and remarried \\
\hline Lauren & 50 & Cleaner & $\mathrm{C}$ & Married for 31 years \\
\hline
\end{tabular}

Note: For race, $C$ represents 'Caucasian', $A$ represents 'Afro-Caribbean' and $M$ represents 'Mixed race' 


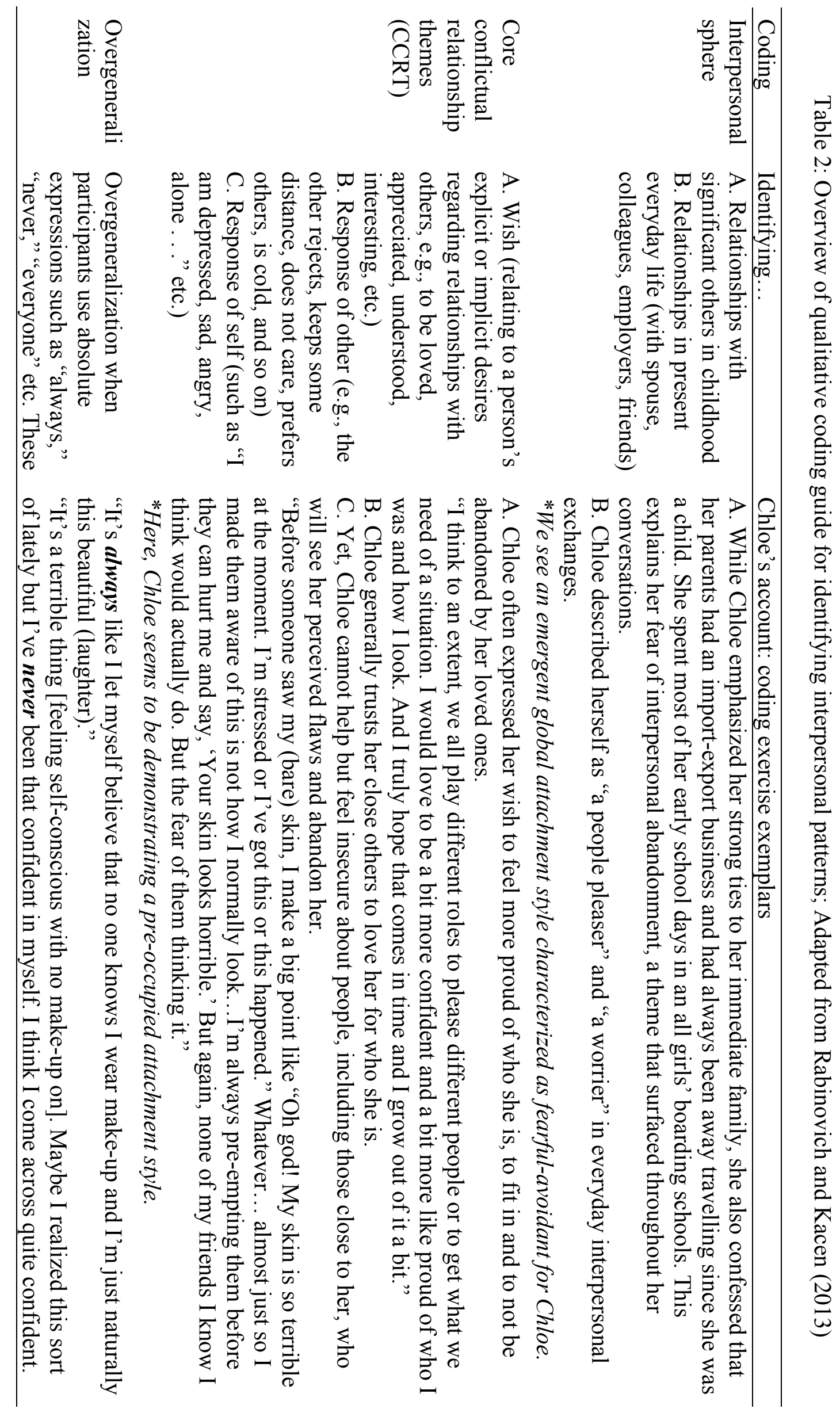




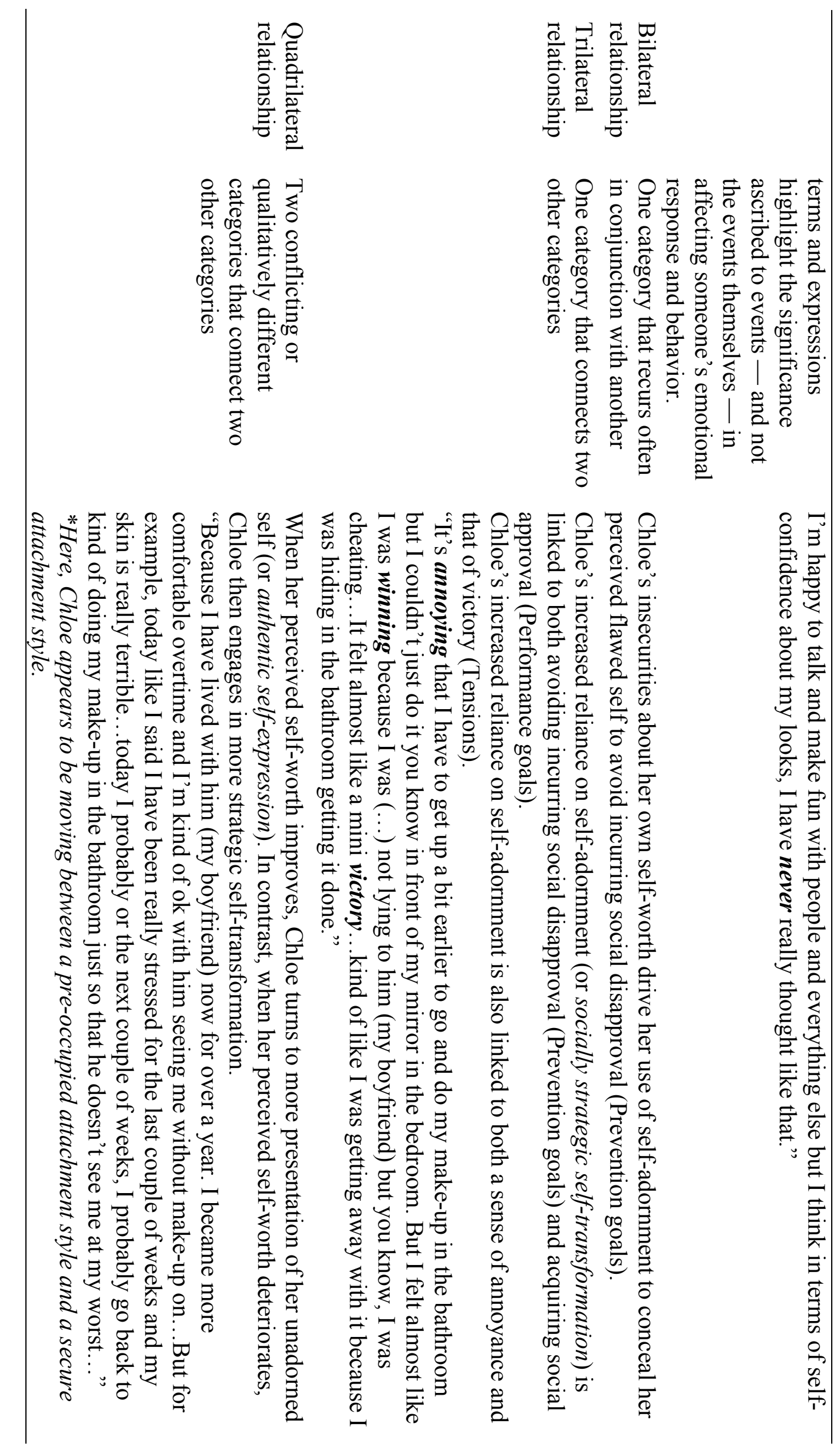




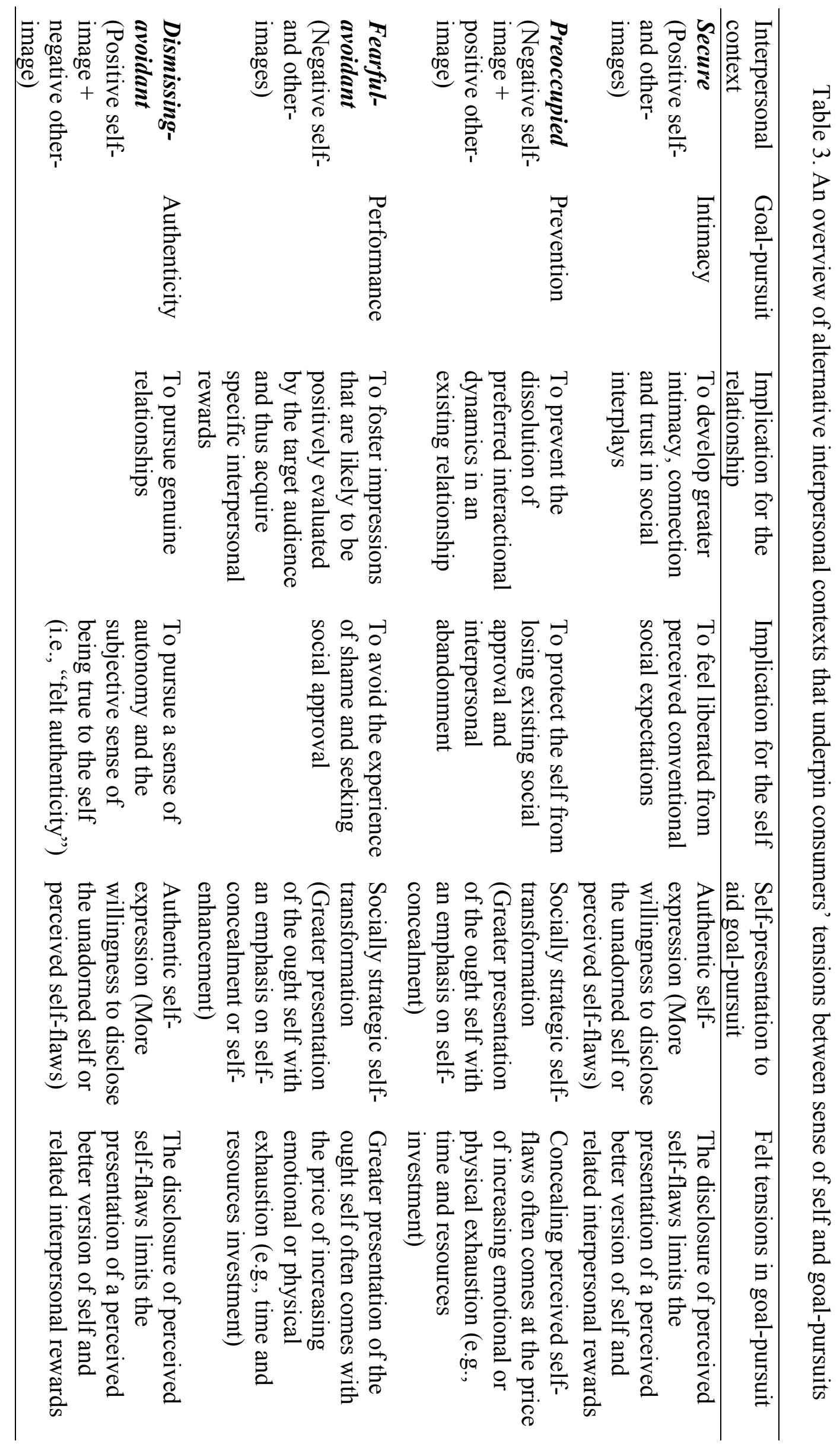



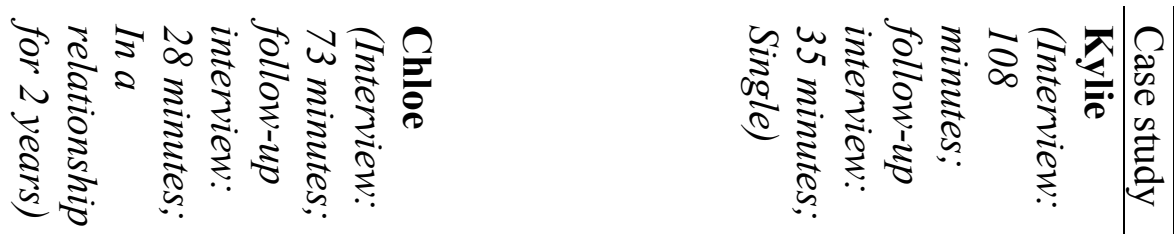

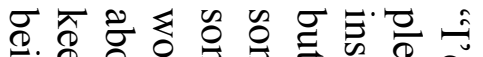

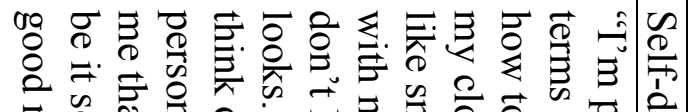

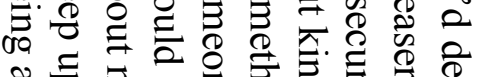

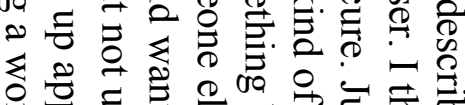

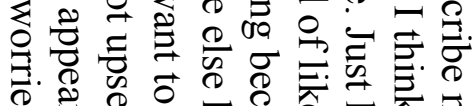

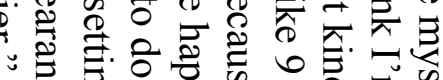

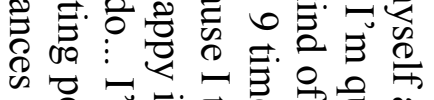

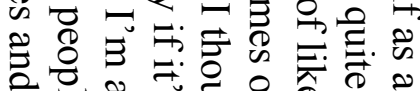

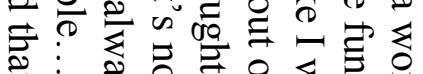

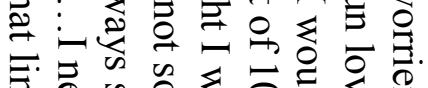
E.

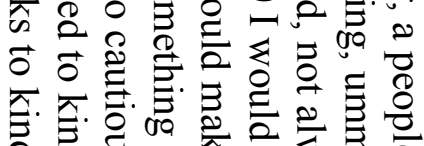

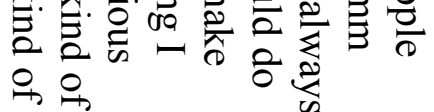

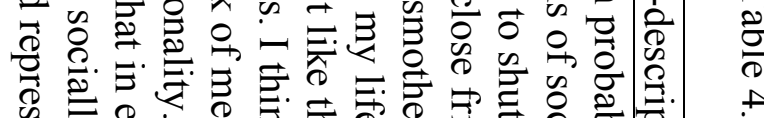

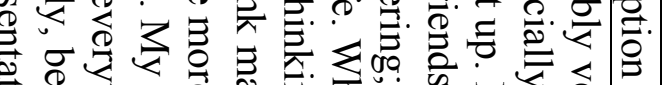
. ㄹ.广

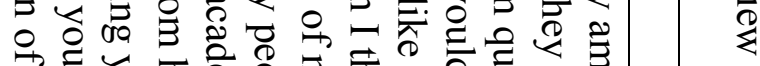

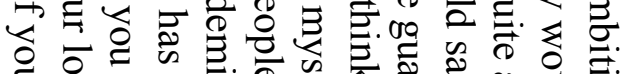

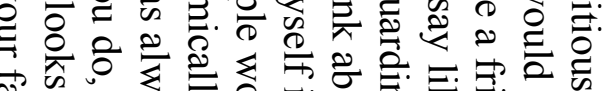

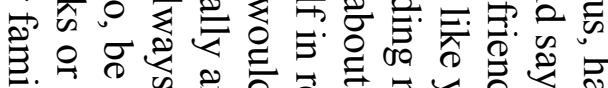

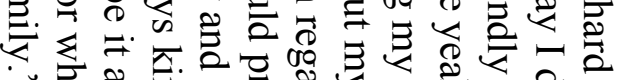
:

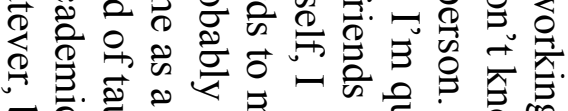

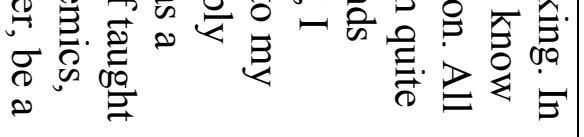

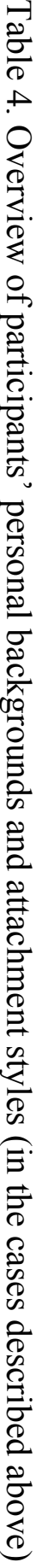

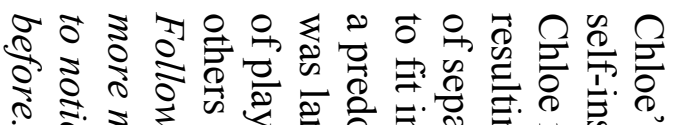

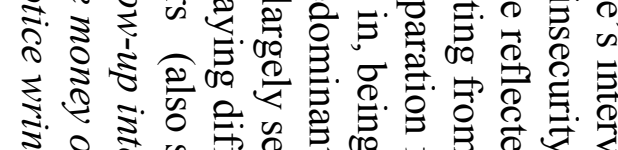

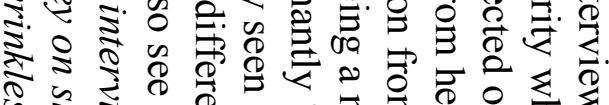
ई

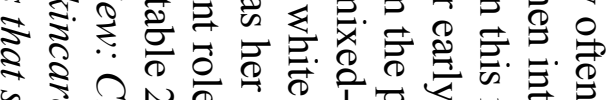

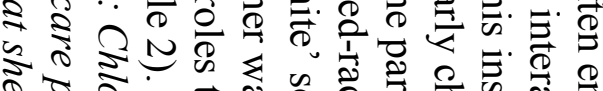

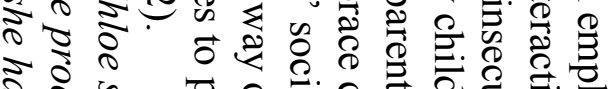

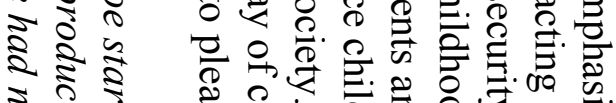

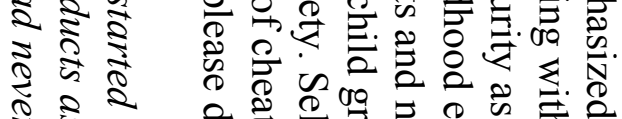

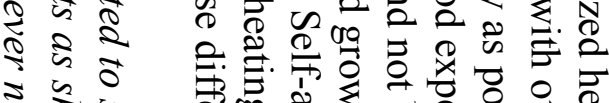

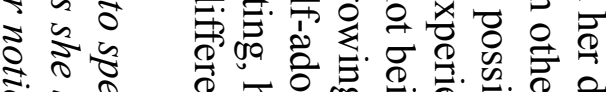

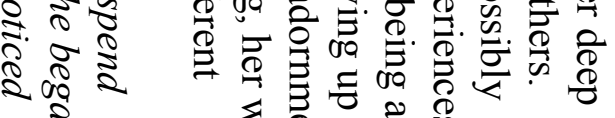

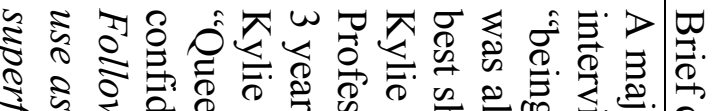

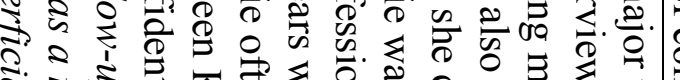
ミ.

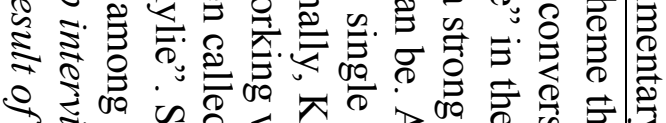

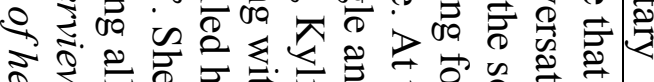

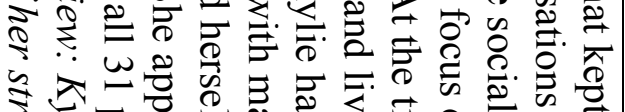

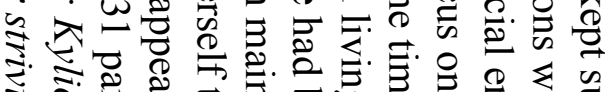

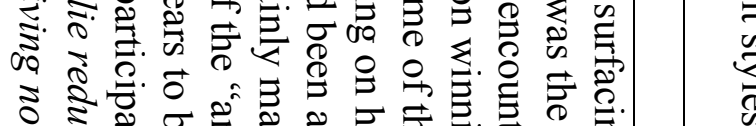

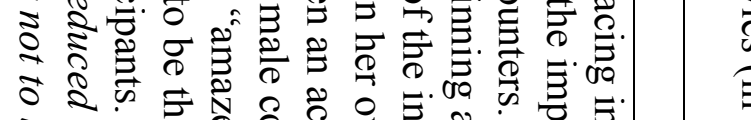
จ

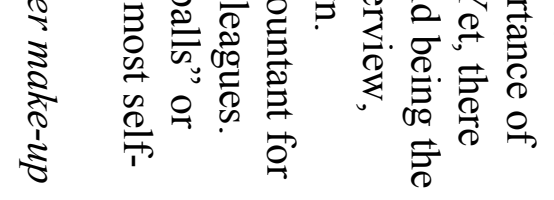
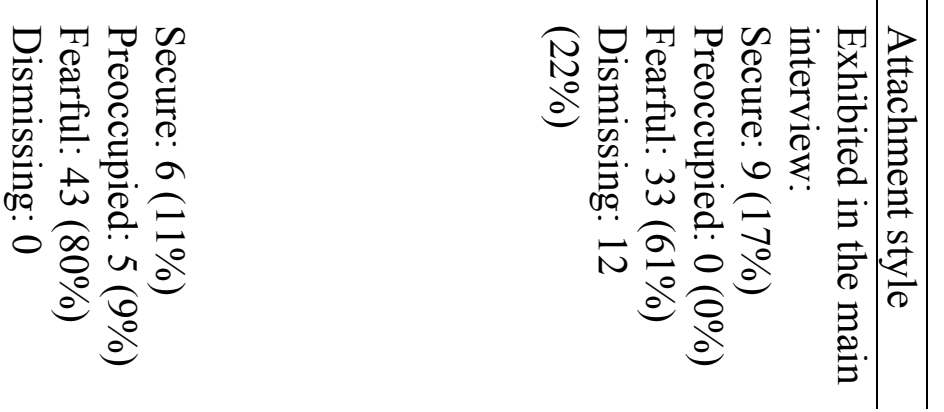

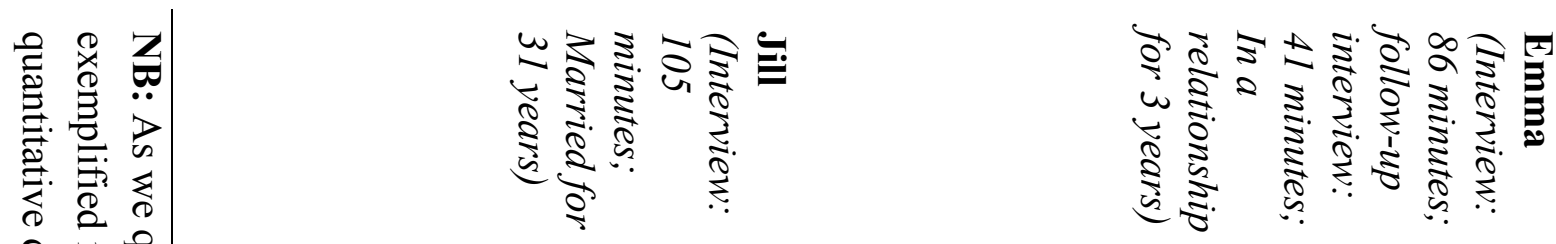

劳 专

P

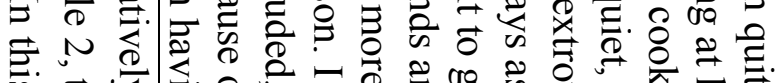

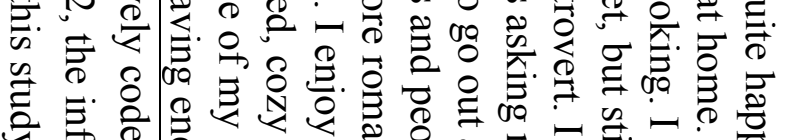

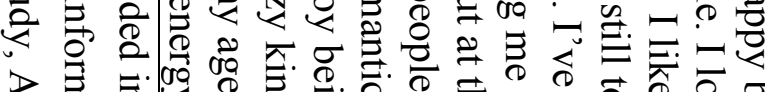

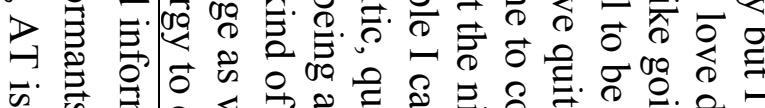

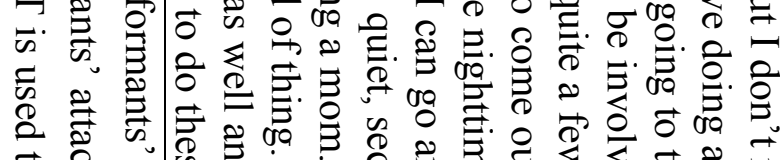

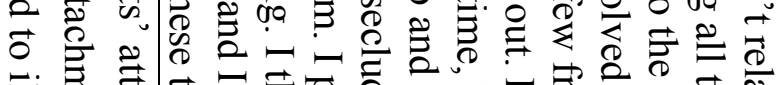

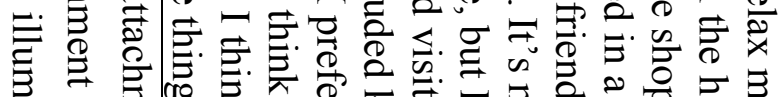

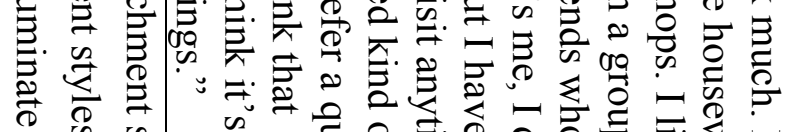

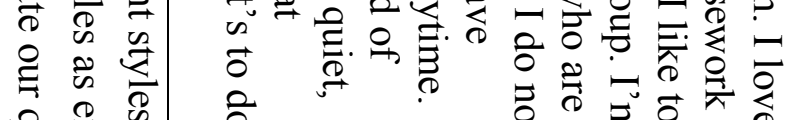

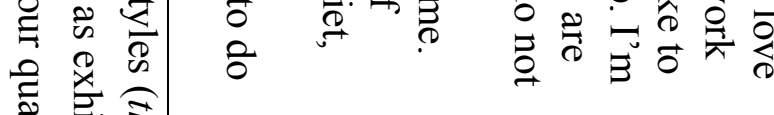

बิ के

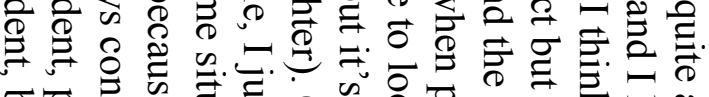

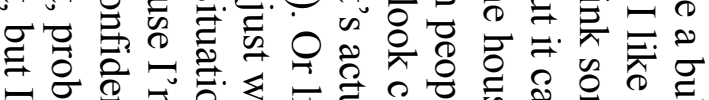

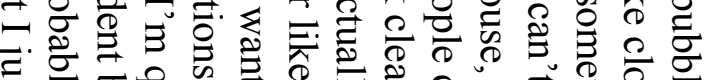

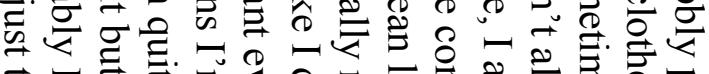

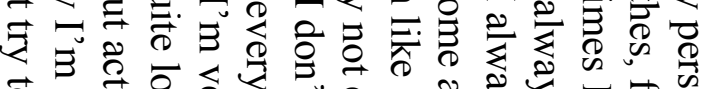

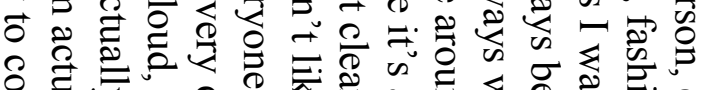

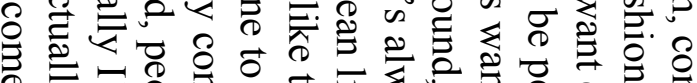
จ

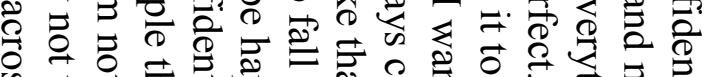

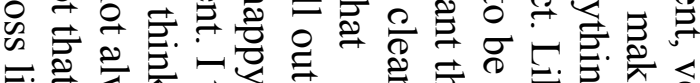

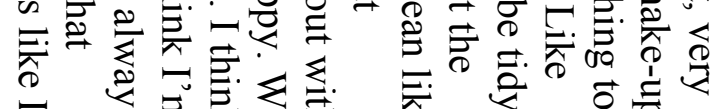

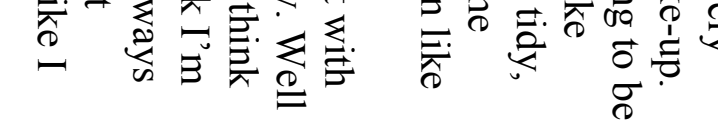

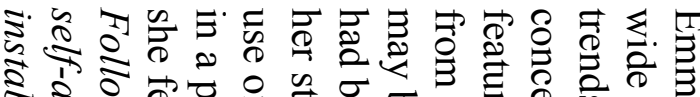

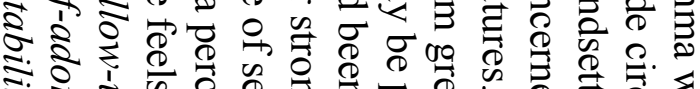

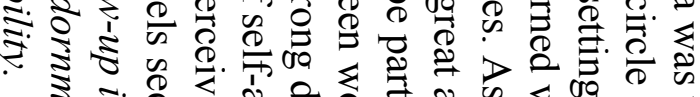

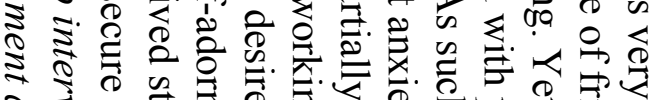

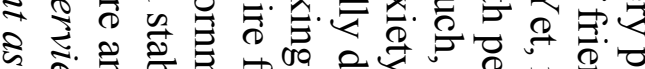
क ई 范

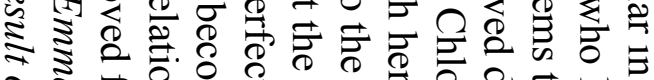
웅유

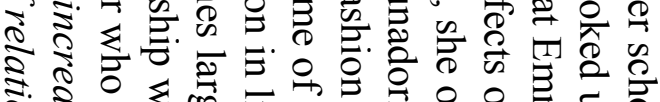

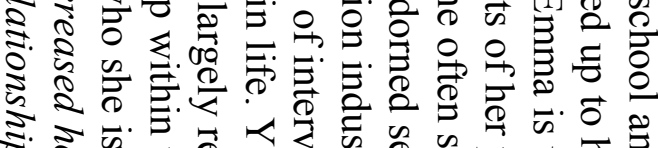

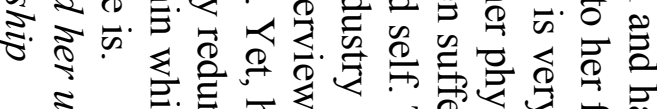

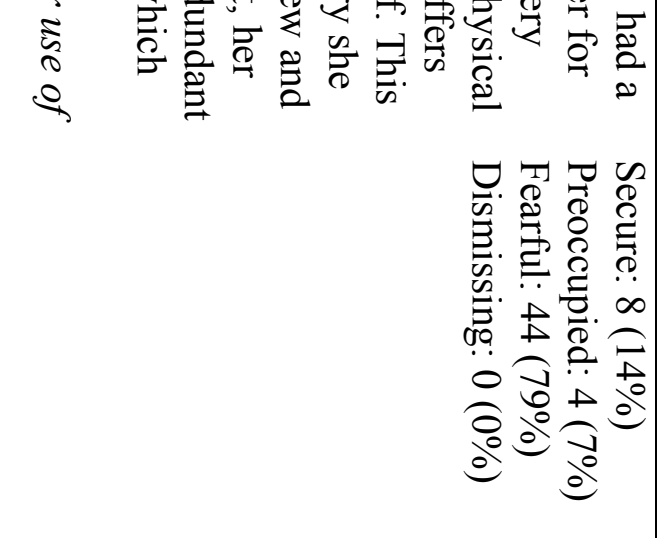

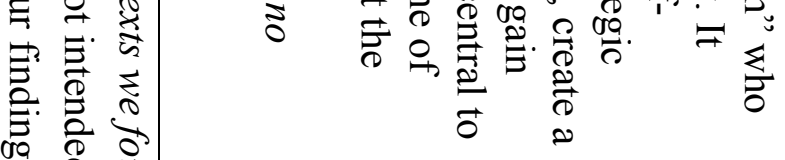

